\title{
Metrics to analyze and improve diets through food Systems in low and Middle Income Countries
}

\author{
Mequanint B. Melesse ${ }^{1,2} \cdot$ Marrit van den Berg ${ }^{1}$ (1) $\cdot$ Christophe Béné ${ }^{3} \cdot$ Alan de Brauw $^{4} \cdot$ Inge D. Brouwer $^{1,5}$
}

Received: 12 March 2019 / Accepted: 20 July 2020 / Published online: 30 August 2020

(C) The Author(s) 2020

\begin{abstract}
Taking a food systems approach is a promising strategy for improving diets. Implementing such an approach would require the use of a comprehensive set of metrics to characterize food systems, set meaningful goals, track food system performance, and evaluate the impacts of food system interventions. Food system metrics are also useful to structure debates and communicate to policy makers and the general public. This paper provides an updated analytical framework of food systems and uses this to identify systematically relevant metrics and indicators based on data availability in low and middle income countries. We conclude that public data are relatively well available for food system drivers and outcomes, but not for all of the food system activities. With only minor additional investments, existing surveys could be extended to cover a large part of the required additional data. For some indicators, however, targeted data collection efforts are needed. As the list of indicators partly overlaps with the indicators for the Sustainable Development Goals (SGDs), part of the collected data could serve not only to describe and monitor food systems, but also to track progress towards attaining the SDGs.
\end{abstract}

Keywords Food systems $\cdot$ Metrics $\cdot$ Indicators $\cdot$ SDGs

\section{Introduction}

Improving diets features high on the global development agenda. A notable share of the world population faces at least one of the three forms of malnutrition - undernutrition, micronutrient malnutrition, or overweight and obesity (e.g. Padilla et al., 2015; IFPRI, 2016). While diets are rapidly changing, they are not necessarily improving (Pingali, 2007; Popkin, 2014). Dietary transitions typically imply increased consumption of animal fats, sugars, and processed foods (Hawkes et al., 2012; Imamura et al., 2015). To stimulate changes towards healthier diets, numerous policies, projects, and programs have been implemented (e.g.

Marrit van den Berg

marrit.vandenberg@wur.nl

1 Development Economics Group, Wageningen University, P.O. Box 8130, 6700, EW Wageningen, the Netherlands

2 ICRISAT, Hyderabad, Telangana, India

3 CIAT, Cali, Valle del Cauca, Colombia

4 IFPRI, Washington, D.C., USA

5 Division of Human Nutrition, Wageningen University, Wageningen, the Netherlands
Fiorella et al., 2016; Allen and De Brauw, 2018). However, these interventions often narrowly focus on specific consumer groups or foods and rarely take a whole diet approach.

Recently, a growing literature has emphasized the importance of approaching diet improvement from a food systems perspective (e.g. Miller and Welch, 2013; Sundaram, 2014; Allen and Prosperi, 2016; Gustafson et al., 2016; Caron et al., 2018). Food systems shape diets and are characterized by multiple interactions, tradeoffs and feedback mechanisms. For example, food systems have been shown to put stress on the environment and its natural resource base by degrading soils, polluting and exhausting fresh water supplies, encroaching on forests, depleting wild fish stocks and reducing biodiversity (FAO, 2013; Prosperi et al., 2014; Westhoek et al., 2016). Consequently, dietary challenges will potentially be best addressed using analytical methods that aim at understanding complex systems (Popkin, 2014). In particular, adopting a food systems approach to diet improvement would facilitate the identification of leverage points for systemic changes, accounting for the full range of interactions, tradeoffs, and system dynamics (Ericksen, 2008; Foran et al., 2014; Dentoni et al., 2017).

Implementing such a food systems approach, however, would require the use of a comprehensive set of metrics. In the context of this paper, a food system metric is 
conceptualized as a system of relevant indicators that provide a tool for measurement, comparison or tracking system performance (Padilla et al., 2015). Food systems metrics are important to describe the current state of food systems, facilitate quantifying relationships needed for exploring causal mechanisms, set baselines against which to measure progress on key goals, evaluate impacts of system transitions and proposed changes, gauge efficacy of interventions, and ultimately facilitate the scaling up of successful interventions (Allen and Prosperi, 2014; Global Panel, 2015; McDermott et al., 2015; IFPRI, 2016). Food system metrics and indicators are also useful to structure high-level debates and communicate the complexity of the system as well as data from science to policy makers or the general public (Gustafson et al., 2016; Lehtonen et al., 2016). As such, they are instrumental to create awareness and improve transparency, beyond being used as monitoring and evaluation tools. Ideally, a common set of indicators could be used across countries and over time to allow comparison.

The aim of this paper is to synthesize existing knowledge and propose an integrated set of food systems metrics that can be readily applied to facilitate food system research and allow cross-case comparison. To ensure that the set of metrics is comprehensive, we base it on a conceptual framework delineating all key food systems components (Ericksen, 2008; Eakin et al., 2016). To allow practical applicability, we limit ourselves to indicators for which data is covered in datasets widely available for low and middle income countries (LMICs): Living Standards Measurement and related Surveys (LSMS), Demographic and Health Surveys (DHS), and publicly available sources of aggregate data, like FAOSTAT and the World Development Indicators. The metrics are thus defined, and can work best, at national and subnational scales. To link this discussion to the broader debate on sustainable development, we prioritize indicators present in the indicator compendium of the Sustainable Development Goals (SDGs). A recent analysis shows that at least 12 of the 17 Goals have strong linkages with food systems (Chaudhary et al., 2018), which illustrates the importance of food systems not only for diets but also for other development outcomes.

We illustrate our approach for four countries that provide relevant case studies for LMICs -Ethiopia, Bangladesh, Nigeria and Vietnam. These countries were chosen as they were recognized to provide a wide range of diet and (sub) national food systems contexts at various stages of food system transformation-from rural (Ethiopia) through mixed (Nigeria and Bangladesh) to urban (Vietnam) with increasing complexity, and urbanization. They are also expected to represent "typical" LMICs in terms of availability (or lack thereof) of national-level data.

There have been a few earlier attempts to develop a series of food system metrics. Notably, Gustafson et al. (2016) propose multidimensional indicators to quantitatively characterize the performance of food systems through seven metrics of sustainable nutrition security. Other recent efforts include Acharya et al. (2014) on assessing sustainable nutrition security, Prosperi et al. (2014) on a vulnerability assessment for the food system of the Mediterranean region, FAO's (2016) compendium of indicators for nutrition-sensitive agriculture, and Zurek et al. (2017) on the sustainability metrics for the European food system. While each of these studies emphasizes the importance of adopting a holistic perspective, none of them covers all dimensions and domains of the food system -see, however, Béné et al. (2019a). Many of the existing studies focus on food system outcomes, without always addressing activities and drivers. As a result, a comprehensive set of metrics to measure the entire food system continues to be a critical knowledge gap (Jones et al., 2013; Global Panel, 2015; McDermott et al., 2015).

Below, we first present a conceptual framework of the food system. Broadly, we distinguish three domains: food system drivers, activities, and outcomes. For each domain, we then propose a comprehensive set of metrics and underlying indicators. Focusing on the four case study countries, we select indicators based on data availability and presence in the SDG indicator compendium. We assess for which metrics data is covered in the relevant datasets and for which metrics additional data collection investments need to be made. We conclude with a discussion on the potential use of the data, the data gaps identified and a cost-effective, high-return strategy for filling those gaps.

\section{A conceptual framework of the food system}

Before considering how food systems can be measured, a clear understanding of the concept of "food system" is essential. Multiple perspectives are found in the literature. Nearly all contain some notion of a "food supply chain," highlighting a series of stages through which food materials are turned into final food products (e.g., Sobal et al., 1998; Grant, 2015), but they are characterized by different levels of recognition of the importance of feedback loops capturing the circular (rather than linear) nature of food systems. Based on elaborated discussions in the context of the CGIAR research Flagship "Food Systems for Healthier Diets", this paper defines food systems broadly as the full set of actors, resources, processes and activities that encompass the domains of food production, processing, distribution, consumption and food waste disposal, and the outcomes of these activities, including nutrition and health, socioeconomic wellbeing and environmental quality, as well as the feedbacks, tradeoffs and synergies between these outcomes.

Food systems are multifaceted and complex-with sociocultural, economic and environmental aspects (e.g., farming, 
food access and equity, food sovereignty) (Pinstrup-Andersen et al., 2011). They involve multiple actors (food producers, food-chain actors, and consumers) operating within dynamic and interactive food environments, with many mechanisms at work across multiple scales and levels (Ericksen, 2008; Eakin et al., 2016; Caron et al., 2018; Turner et al., 2018). Food systems analysis must also consider the governance and political economy of food production, processing and consumption, sustainability of food systems, effects on health and wellbeing, and drivers of system change. A conceptual framework of the food system thus needs to portray different relationships, interactions, tradeoffs, feedback mechanisms and drivers of system changes that ultimately shape system outcomes across several levels.

Several food systems frameworks have been proposed in the literature (e.g. Sobal et al., 1998; Burchi et al., 2011). These frameworks tend to present the food system as a series of ordered and linear stages. While easily tractable and insightful, such a linear representation disregards complex interactions, synergies and feedbacks in the system. Importantly, many of these existing frameworks consider health or diet as the sole outcome of the system (e.g., Sobal et al., 1998; Burchi et al., 2011). Ericksen (2008) proposed a framework that recognizes the complex interactions, synergies and feedbacks, and thus presents a solid foundation for an appropriate conceptualization of food systems.

We largely follow this framework with two amendments (Fig. 1). First, given the focus of this paper on healthier diets, we separate the nutrition element from the broader concept of food security to create a new outcome category. We group the remaining elements of food security under socioeconomic wellbeing. In addition, we include food loss and waste management explicitly as an activity (Jurgilevich et al., 2016; Chaboud and Daviron, 2017). The resulting framework gives a schematic representation of food systems activities and their main outcomes along with system drivers. Food systems activities lie at the center and include food production, processing, distribution and marketing, consumption choices, and food loss and waste management. The key food systems outcomes relate to nutrition and health, socioeconomic wellbeing, and environmental quality. Finally, food systems drivers include biophysical, socioeconomic and natural factors that shape food system activities and outcomes.

Interactions within food systems are complex, and tradeoffs and synergies between various system outcomes must be considered to appropriately reflect the complexity of food systems and the difficulties to navigate between often competing goals (Béné et al. 2019b). For example, avoiding overconsumption and dietary changes, such as reducing the consumption of animal-sourced food and adopting diets with more plant-based products, serve not just dietary outcomes, but can also lead to improved environmental outcomes and reduced risk of diet-related non-communicable diseases
(Tilman and Clark, 2014; van Dooren et al., 2014; Springmann et al., 2016). Yet, at the same time, recommendations to increase, say, the consumption of fruits and vegetables to promote healthier diets can raise questions about the potential consequences of expanding their production, such as increased irrigation water or farm labor, or increased use of pesticides with negative health outcomes (Wirsenius et al., 2010; Becker, 2017). Equally, reducing the consumption of animal-sourced food may negatively affect the livelihoods of livestock farmers. Further, tradeoffs can also exist between short-term gains and long-term costs of interventions. While all actors may agree that improved health and resource sustainability are positive long-term outcomes, present-day choices of consumers and businesses are still determined by costs, prices, convenience and cultural and social values, among other factors, all of which may not reflect good health or sustainable production practices (Nesheim et al., 2015). In sum, deciding among various intervention options can be challenging, and decision makers must possess the right tools for analyzing intended and unintended effects, including isolating underlying causes, understanding how to weigh various tradeoffs and taking advantage of synergies (Béné et al., 2019b).

\section{Research methodology}

We employed a series of processes for the selection of food systems metrics and corresponding indicators for different domains and dimensions of the food system. First, we reviewed the relevant literature and selected/amended a conceptual framework, with the aim of identifying key components of the food system. Second, we identified thematic categories of the food systems metrics and comprehensive sets of underlying indicators following a hierarchical approach based on this framework. We sought to be as comprehensive as possible capturing the various domains and dimensions of the food system in our metrics. Broadly, the identified metrics were grouped into three general thematic categories of metrics: 1) food systems drivers, 2) food systems activities, and 3) food systems outcomes. For each of these metrics categories, we further identified a coherent set of metrics components and corresponding indicators. Third, given the large number of potential indicators, there was a clear need for prioritization and standardization. We use two criteria: 1) data availability in at least one of the four countries; and 2) presence in the compendium of SDG indicators, which has a total of 230 indicators. Table 1 presents the SDGs and shows the overlap with our metrics. Please note that the SDG indicators are often less precise than our indicators, so that we used some expert judgment for matching.

Data availability is a critical dimension of metric construction if indicators are to be easily adopted. We therefore 


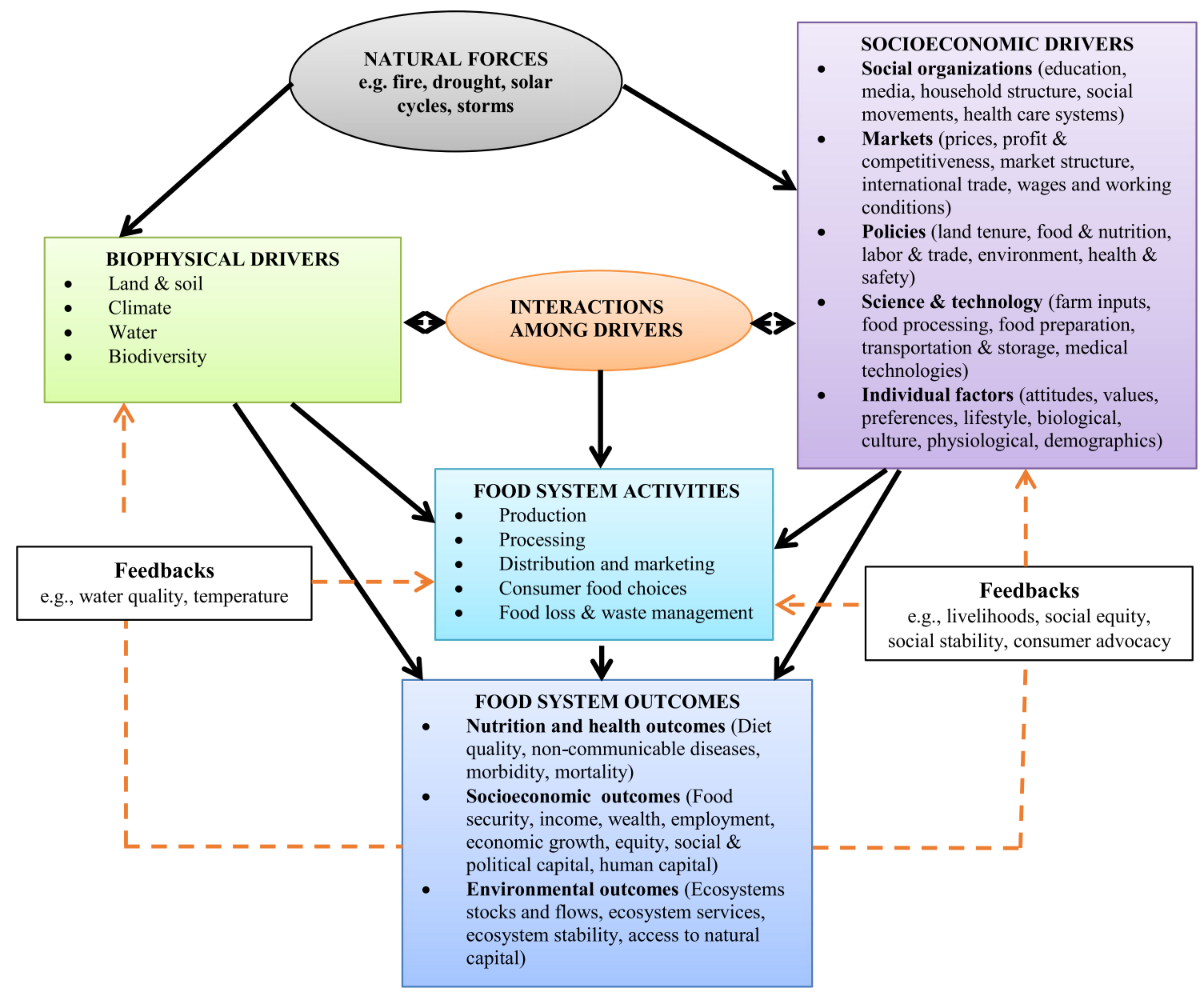

Fig. 1 A conceptual framework of the food system (adapted from Ericksen, 2008)

identified widely available reliable open data sources to draw upon. At the micro-level, these surveys include the LSMS and the DHS. The LSMS and the DHS are representative at the national level. A wide range of topics are covered in these surveys, including household information, farm-related information, crop and livestock production details, agricultural extension services, household food consumption and income sources, among other variables. The LSMS surveys have a good quality rural and urban areas, enabling the surveys to provide reliable comparative analysis for rural and urban areas. Micro-level datasets are particularly useful, as these allow determining indicator values for subsystems or subpopulations and following indicator values throughout the system based on geographic location, food system activity, income, sex, age, race, ethnicity, migratory status, or other characteristics. At a higher (macro) level, aggregate data can be found in databases such as FAOSTAT, the World Development Indicators, AQUASTAT and the World Animal Protection dataset. Those aggregate datasets are also useful as they usually include more ready-to-use indicators. Summaries of these different datasets are provided in the Supplementary
Materials. Data on regulatory bodies and other relevant institutions are available on their own websites.

The four case study countries have a good availability of common data sources. All four have a DHS and Ethiopia, Nigeria and Vietnam have a LSMS. For Bangladesh, we use the BIHS, which is similar to the LSMS but only covers rural areas. For key socio-economic characteristics of the individual countries, please refer to Table 2 .

\section{Food systems metrics}

\subsection{Metrics for food systems drivers}

Understanding drivers of food system changes and transformations is important to assess potential policy or technological options to affect food system actors' decisions and behaviors, and ultimately shape outcomes of food systems (Grant, 2015; McDermott et al., 2015; Béné et al. 2019c). The framework (Fig. 1) broadly describes two types of drivers: biophysical and socioeconomic drivers. Biophysical drivers include environmental changes that affect food system activities and 
Table 1 Sustainable Development Indicators

\begin{tabular}{lll}
\hline & Sustainable Development Goal & Food system metric with similar indicators \\
\hline 1 & No Poverty & Socioeconomic outcomes \\
2 & Zero Hunger & $\begin{array}{c}\text { Diet, nutrition and health outcomes, environmental } \\
\text { outcomes, food production }\end{array}$ \\
3 & Good Health and Well-being & Diet, nutrition and health outcomes \\
4 & Quality Education & \\
5 & Gender Equality & Socioeconomic outcomes \\
6 & Clean Water and Sanitation & Diet, nutrition and health outcomes, socioeconomic \\
& & outcomes, environmental outcomes, food loss and \\
7 & Affordable and Clean Energy & waste \\
8 & Decent Work and Economic Growth & Socioeconomic outcomes \\
9 & Industry, Innovation and Infrastructure & Socioeconomic drivers, socioeconomic outcomes \\
& & Environmental outcomes, socioeconomic drivers, food \\
& & production, food processing, food distribution and \\
10 & Reduced Inequality & Socioeconomic outcomes \\
11 & Sustainable Cities and Communities & \\
12 & Responsible Consumption and Production & Food loss and waste, environmental outcomes \\
13 & Climate Action & \\
14 & Life Below Water & Environmental outcomes \\
15 & Life on Land & Environmental outcomes \\
16 & Peace, Justice, and Strong Institutions & \\
\hline
\end{tabular}

outcomes through impacts on the quality and availability, notably climate change, deforestation, soil erosion, and reduced pollinators and ground water for irrigation. On the other hand, socioeconomic drivers comprise a wide range of social and institutional factors, including market forces, social organizations, science and technology, policies, and consumer preferences and norms, which also shape the ways in which food systems evolved and operate (Nesheim et al., 2015; Béné et al. 2019c). To combine these concepts, several indicators that capture essential drivers of food systems, mostly available from FAOSTAT can be identified. Table 3 shows that only a limited number of them is part of the SDG indicators. Data on drivers at subnational level is not available.

\subsection{Metrics for measuring food system activities}

Food system activities form the core of the system. The principal activities of the food system encompass food production, processing, distribution and marketing, consumption, and food loss and waste management. Metrics for food system activities largely reflect economic measures and are important to assess the economic performance of the systems.

\subsubsection{Food production}

Food production is the principal determinant of food availability in most economies (Ericksen, 2008). It includes all
Table 2 Selected sociodemographic features of the study countries

\begin{tabular}{lllll}
\hline Variables & Bangladesh & Ethiopia & Nigeria & Vietnam \\
\hline Total population & $159,685,424$ & $106,399,924$ & $190,873,244$ & $94,600,648$ \\
Share urban & $37 \%$ & $20 \%$ & $50 \%$ & $36 \%$ \\
Per capita income (US\$) & 1492 & 720 & 1969 & 2342 \\
Stunting & $36.1 \%$ & $40.4 \%$ & $32.9 \%$ & $19.4 \%$ \\
Wasting & $14.3 \%$ & $8.7 \%$ & $7.9 \%$ & $5.7 \%$ \\
Underweight & $32.6 \%$ & $25.2 \%$ & $19.8 \%$ & $12.1 \%$ \\
Child overweight & $1.4 \%$ & $2.6 \%$ & $1.8 \%$ & $4.6 \%$ \\
\hline
\end{tabular}

Note: Nutrition outcomes for children under five in 2014 (WHO database) and other sociodemographic variables in 2017 (FAOSTAT) 
Table 3 Indicators for the drivers of food systems

\begin{tabular}{|c|c|c|c|c|c|c|c|c|}
\hline $\begin{array}{l}\text { Metric } \\
\text { components }\end{array}$ & Indicators & Description & Data source & Bangladesh & Ethiopia & Nigeria & Vietnam & $\begin{array}{l}\text { Present in } \\
\text { SDG } \\
\text { indicators }\end{array}$ \\
\hline \multirow[t]{3}{*}{$\begin{array}{l}\text { Biophysical } \\
\text { drivers }\end{array}$} & Climate change & $\begin{array}{l}\text { The change in average temperature of a } \\
\text { specific area (location) over time. }\end{array}$ & FAOSTAT & A & A & A & A & No \\
\hline & $\begin{array}{l}\text { Deforestation } \\
\text { rate }\end{array}$ & $\begin{array}{l}\text { The average annual rate at which natural } \\
\text { forest area is permanently converted to } \\
\text { other uses, including shifting cultivation, } \\
\text { permanent agriculture, ranching, } \\
\text { settlements, and infrastructure } \\
\text { development. }\end{array}$ & FAOSTAT & $\mathrm{A}$ & A & A & A & No \\
\hline & Soil erosion & Tons of topsoil lost per year due to erosion & FAOSTAT & $\mathrm{A}$ & A & A & A & No \\
\hline \multirow[t]{7}{*}{$\begin{array}{l}\text { Socioeconomic } \\
\quad \text { drivers }\end{array}$} & $\begin{array}{l}\text { Economic } \\
\text { development }\end{array}$ & $\begin{array}{l}\text { The level of GDP and/or growth rate of } \\
\text { GDP per capita of a country (region) }\end{array}$ & FAOSTAT & A & A & A & A & Yes \\
\hline & $\begin{array}{l}\text { Technological } \\
\text { change }\end{array}$ & $\begin{array}{l}\text { The annual per capita public and private } \\
\text { expenditure on R\&D in the food } \\
\text { production and processing sector }\end{array}$ & - & NA & NA & NA & NA & Yes \\
\hline & $\begin{array}{l}\text { Population } \\
\text { dynamics }\end{array}$ & $\begin{array}{l}\text { Population growth rate and associated } \\
\text { demographic changes, like shares of the } \\
\text { young, working age, and old age }\end{array}$ & FAOSTAT & A & A & A & A & No \\
\hline & $\begin{array}{l}\text { Food price } \\
\text { trends }\end{array}$ & $\begin{array}{l}\text { Developments of aggregated and } \\
\text { disaggregated (e.g., producer vs. } \\
\text { consumer price indices, or nutritious vs. } \\
\text { less nutritious food price indices) food } \\
\text { prices over time or volatility in food } \\
\text { prices over time. }\end{array}$ & FAOSTAT & $\mathrm{A}$ & A & NA & A & No \\
\hline & $\begin{array}{l}\text { Consumer } \\
\quad \text { organizations }\end{array}$ & $\begin{array}{l}\text { Number of consumer organizations that are } \\
\text { active and present at a national/regional } \\
\text { level }\end{array}$ & $\begin{array}{l}\text { National } \\
\text { consumer } \\
\text { associa- } \\
\text { tions }\end{array}$ & $\mathrm{A}$ & A & A & A & No \\
\hline & Urbanization & $\begin{array}{l}\text { Change in the percentage of the total } \\
\text { population who reside in urban areas }\end{array}$ & FAOSTAT & A & A & $\mathrm{A}$ & A & No \\
\hline & Public policy & $\begin{array}{l}\text { Indicators measuring the presence of public } \\
\text { policies and programs (farm, health and } \\
\text { safety, labor and trade, environment and } \\
\text { energy policies) that have direct } \\
\text { implications for activities and } \\
\text { organizations of food systems }\end{array}$ & $\begin{array}{c}\text { Government } \\
\text { web sites }\end{array}$ & $\mathrm{A}$ & A & A & A & No \\
\hline
\end{tabular}

Notes: A = Publicly available and NA = Currently not available; LSMS: This involves integrated household surveys that from part of the LSMS program or similar surveys. ${ }^{1}$ Consumers Association of Bangladesh, Ethiopian Consumers Protection Association, Consumer Awareness Organization for Nigeria, Vietnam Standards and Consumers Association

activities involved in the production of raw food materials, harvesting, raising livestock and activities related to fisheries. A (food) production system is characterized by its use of inputs (both natural resources and technologically improved varieties), productivity, and output levels. Relevant food production metrics should measure input utilization, productivity, and output levels in a given geographic area over a specific time period. Table 4 shows that sufficient information is available in the LSMS and FAOSTAT to generate a consistent set of indicators for these variables, though not equally complete for all four countries considered in this study. Notably, data about the use of high yielding varieties and biofortified seeds is collected in only two out of the four countries. Table 1 shows, however, that on the other hand, the SDGs make limited reference to food production: indicators are limited to the use of improved seeds and breeds and organic farming. Data on the latter is not routinely collected in the LSMS.

\subsubsection{Food processing}

Food processing consists of all processes that modify the original nature, content and/or appearance of the raw materials, including transforming it into more elaborated food products, as well as packaging and labelling (Ericksen, 2008; Ingram, 2009). These processes can substantially alter, reduce or improve the nutritional value, appearance, storage life, safety and content of the raw food materials (Miller and Welch, 2013). Food processing can also considerably reduce the time and energy required for home food preparation. The analysis (Table 5) shows that while data is available on the size of 
Table 4 Indicators of the food production metric

\begin{tabular}{|c|c|c|c|c|c|c|c|c|}
\hline $\begin{array}{l}\text { Metric } \\
\text { components }\end{array}$ & Indicators & Description & Data source & Bangladesh & Ethiopia & Nigeria & Vietnam & $\begin{array}{l}\text { Present in } \\
\text { SDG } \\
\text { indicators }\end{array}$ \\
\hline \multirow[t]{8}{*}{ Inputs } & $\begin{array}{l}\text { High Yielding } \\
\text { Varieties Seeds }\end{array}$ & $\begin{array}{l}\text { Quantity of high yield hybrid seed } \\
\text { varieties used per hectare of } \\
\text { arable land }\end{array}$ & LSMS & A & NA & $\mathrm{A}$ & NA & Yes \\
\hline & Biofortified seeds & $\begin{array}{l}\text { Quantity of biofortified seeds used } \\
\text { per hectare of arable land }\end{array}$ & LSMS & NA & A & A & NA & Yes \\
\hline & Improved breeds & Total number of improved breeds & LSMS & A & A & A & A & Yes \\
\hline & $\begin{array}{l}\text { Number of organic } \\
\text { farms }\end{array}$ & $\begin{array}{l}\text { Total number of farms engaged in } \\
\text { organic production weighted by } \\
\text { land area }\end{array}$ & - & NA & NA & NA & NA & Yes \\
\hline & $\begin{array}{l}\text { Fertilizer use per unit } \\
\text { of land }\end{array}$ & $\begin{array}{l}\text { Quantity of fertilizer used per } \\
\text { hectare of arable land }\end{array}$ & LSMS & $\mathrm{A}$ & $\mathrm{A}$ & $\mathrm{A}$ & A & No \\
\hline & $\begin{array}{l}\text { Agricultural water } \\
\text { withdrawal }\end{array}$ & $\begin{array}{l}\text { Annual quantity of self-supplied } \\
\text { water withdrawal for irrigation, } \\
\text { livestock and aquaculture pur- } \\
\text { poses }\end{array}$ & AQUASTAT & NA & A & NA & NA & No \\
\hline & Crop land & $\begin{array}{l}\text { Percentage of cultivable land used } \\
\text { for crop production in hectares }\end{array}$ & FAOSTAT & A & A & A & A & No \\
\hline & Livestock statistics & $\begin{array}{l}\text { Per capita number of cattle, shoats, } \\
\text { and other animal food sources, } \\
\text { like chickens }\end{array}$ & FAOSTAT & NA & A & A & A & No \\
\hline \multirow[t]{3}{*}{ Productivity } & $\begin{array}{l}\text { Agriculture factor } \\
\text { productivity }\end{array}$ & $\begin{array}{l}\text { Average yields of cereals and } \\
\text { pulses; agricultural labor } \\
\text { productivity; land productivity; } \\
\text { total factor productivity (TFP) }\end{array}$ & LSMS/FAOSTAT & $\mathrm{A}$ & A & $\mathrm{A}$ & A & No \\
\hline & $\begin{array}{l}\text { Yield gaps for key } \\
\text { staple crops }\end{array}$ & $\begin{array}{l}\text { Measure of how close each country } \\
\text { is to achieving their potential in } \\
\text { production }\end{array}$ & FAOSTAT & $\mathrm{A}$ & A & $\mathrm{A}$ & A & No \\
\hline & Agricultural R\&D & $\begin{array}{l}\text { Public expenditure on agricultural } \\
\text { R\&D in percentage of GDP }\end{array}$ & FAOSTAT & $\mathrm{A}$ & $\mathrm{A}$ & $\mathrm{A}$ & $\mathrm{A}$ & No \\
\hline \multirow[t]{2}{*}{ Output } & Crop output & $\begin{array}{l}\text { Physical quantity or value of each } \\
\text { main crop produced in a given } \\
\text { geographic area. }\end{array}$ & LSMS/FAOSTAT & A & A & $\mathrm{A}$ & A & No \\
\hline & Animal food products & $\begin{array}{l}\text { The total quantity or value of each } \\
\text { animal food product (dairy } \\
\text { products, meat, fish and egg) }\end{array}$ & LSMS/FAOSTAT & A & A & A & A & No \\
\hline
\end{tabular}

Notes: A = Publicly available and NA = Currently not available; LSMS: This involves integrated household surveys that from part of the LSMS program or similar surveys

the processing industry in the LSMS (local industry only), this information does not reveal much about the nature of the transformations and their impact on food quality, with the exception of the number of foods that are commonly fortified. Likewise, the SDGs only refer to the number of small and medium enterprises operating in the food sector in a country or region.

\subsubsection{Food distribution and marketing}

A well-functioning food distribution and marketing system is an integral component of the food system activities, and involves transporting, storing and marketing food products to consumers (Ingram, 2009). Food distribution consists of several facilities and actors, including wholesalers, brokers, food warehouses, logistics and other distribution channels. The performance of the distribution and marketing sector is strongly determined by transportation and infrastructure availability, storage facilities, cold chains and the organizational structure of markets. Table 6 shows that at the present time, data on these processes is limited, leading to a small set of available indicators with partial coverage. The SDG indicators include road density and competitiveness (of the food sector) in the world market, which could serve as proxies, though very rough, for transportation and marketing. FAOSTAT and the World Development Indicators both include data on competitiveness. Information about storage capacity is included in the LSMS survey for Bangladesh and to a limited extent Ethiopia and Nigeria, but not for Vietnam, where the data only cover the storage of harvests by farmers. Hence, good metrics for food distribution and marketing are quite incomplete (Table 6). 
Table 5 Indicators of the food processing metric

\begin{tabular}{|c|c|c|c|c|c|c|c|}
\hline Indicators & Description & $\begin{array}{l}\text { Data } \\
\text { source }\end{array}$ & Bangladesh & Ethiopia & Nigeria & Vietnam & $\begin{array}{l}\text { Present in } \\
\text { SDG } \\
\text { indicators }\end{array}$ \\
\hline $\begin{array}{l}\text { Small \& medium } \\
\text { enterprises in the } \\
\text { food sector }\end{array}$ & $\begin{array}{l}\text { Number of small and medium enterprises operating in the food } \\
\text { sector in a country or region }\end{array}$ & LSMS & A & NA & A & A & Yes \\
\hline $\begin{array}{l}\text { Food processing } \\
\text { industry }\end{array}$ & $\begin{array}{l}\text { Numbers of food processing firms and manufacturers, dairy } \\
\text { processors, and slaughterhouses and meat processors in a } \\
\text { country or region }\end{array}$ & LSMS & $\mathrm{A}$ & A & $\mathrm{A}$ & $\mathrm{A}$ & No \\
\hline $\begin{array}{l}\text { Value added in the } \\
\text { food industry }\end{array}$ & $\begin{array}{l}\text { The economic value added of the food processing sector as a } \\
\text { percentage of the total food value }\end{array}$ & - & NA & NA & NA & NA & No \\
\hline Fortified food & $\begin{array}{l}\text { Number of commonly consumed foods that are fortified in a } \\
\text { country or region }\end{array}$ & LSMS & A & A & A & A & No \\
\hline
\end{tabular}

Notes: A = Publicly available and NA = Currently not available; LSMS: This involves integrated household surveys that from part of the LSMS program or similar surveys

\subsubsection{Consumption}

Food consumption is a key outcome of food systems, closely related to food utilization and individual or collective health outcomes. Food consumption can be thought of as including decisions about what to purchase as well as food preparation and eating habits, along with actual food intakes. According to Just and Gabrielyan (2016), understanding food consumption behavior can (i) help to link nutrition demand with economic value to create business opportunities, and (ii) open opportunities to minimize threats that might be presented by transition processes of the food system. Income levels, tastes, preferences, social values, health status, socioeconomic status, ease of

Table 6 Indicators of the food distribution and marketing metric

\begin{tabular}{|c|c|c|c|c|c|c|c|c|}
\hline $\begin{array}{l}\text { Metric } \\
\text { components }\end{array}$ & Indicators & Description & Data source & Bangladesh & Ethiopia & Nigeria & Vietnam & $\begin{array}{l}\text { Present in } \\
\text { SDG } \\
\text { indicators }\end{array}$ \\
\hline Transportation & Road density & $\begin{array}{l}\text { Road density is the ratio of the length of } \\
\text { the country's total road network to the } \\
\text { country's land area. The road network } \\
\text { includes all roads in the country: } \\
\text { motorways, highways, main or } \\
\text { national roads, secondary or regional } \\
\text { roads, and other urban and rural roads. }\end{array}$ & - & NA & NA & NA & NA & Yes \\
\hline Food marketing & $\begin{array}{l}\text { Competitiveness } \\
\text { in trade }\end{array}$ & $\begin{array}{l}\text { The share of food exports in the total } \\
\text { gross value of exports of a } \\
\text { country/region to the world market, } \\
\text { which indicates competitiveness of the } \\
\text { food sector in the world market com- } \\
\text { pared to other products in the } \\
\text { country/region }\end{array}$ & $\begin{array}{l}\text { FAOSTAT; } \\
\text { World } \\
\text { Bank }\end{array}$ & A & A & A & A & Yes \\
\hline \multirow[t]{3}{*}{ Storage } & Food warehousing & $\begin{array}{l}\text { Number and capacity of food storage } \\
\text { warehouses available in a region }\end{array}$ & LSMS & A & NA & NA & NA & No \\
\hline & Cold storage & $\begin{array}{l}\text { The total volume of both public and } \\
\text { private cold storage facilities available } \\
\text { for warehousing and transporting of } \\
\text { perishable food products (like meats, } \\
\text { fish and fruits/vegetables) in a country } \\
\text { or region }\end{array}$ & LSMS & $\mathrm{A}$ & NA & NA & NA & No \\
\hline & $\begin{array}{l}\text { Contingency } \\
\text { food storage }^{2}\end{array}$ & $\begin{array}{l}\text { An indicator for the presence of a } \\
\text { contingency community food storage } \\
\text { facility in a given region }\end{array}$ & LSMS & $\mathrm{A}$ & A & $\mathrm{A}$ & NA & No \\
\hline
\end{tabular}

Notes: A = Publicly available and NA = Currently not available; LSMS: This involves integrated household surveys that from part of the LSMS program or similar surveys. ${ }^{1}$ FAOSTAT: data on export of food products and World Bank: data on total export; ${ }^{2}$ Data on how much of the harvest is stored for Ethiopia and Nigeria 
access to food and commercial advertising and prices are among the main factors that drive the type and nutrient quality of consumers' food choices (Ericksen, 2008; Nesheim et al., 2015). Food consumption behavior metrics should include indicators capturing capacity including consumers' economic resources, nutrition knowledge and consumer advocacy. The analysis (Table 7) shows that while the SDG indicators do not explicitly refer to the capacity to consume, the LSMS cover food expenditures, time availability for food preparation (though not in Nigeria), nutrition knowledge (Bangladesh only) and government food and safety net policies. Similarly, the SDGs do not include consumer advocacy, but data on consumer associations are available on the web. As diets are also key outcomes, we will discuss diet indicators in the outcome section.

Table 7 Indicators of the food consumption behavior metric

\begin{tabular}{|c|c|c|c|c|c|c|c|c|}
\hline $\begin{array}{l}\text { Metric } \\
\text { components }\end{array}$ & Indicators & Description & Data source & Bangladesh & Ethiopia & Nigeria & Vietnam & $\begin{array}{l}\text { Present in } \\
\text { SDG } \\
\text { indicators }\end{array}$ \\
\hline \multirow[t]{9}{*}{ Capacity } & Expenditure on food & Value of household food expenditures & LSMS & A & A & A & A & No \\
\hline & $\begin{array}{l}\text { Time available for } \\
\text { food preparation }\end{array}$ & $\begin{array}{l}\text { Average time available for household } \\
\text { food preparation in a day }\end{array}$ & LSMS & A & A & NA & A & No \\
\hline & $\begin{array}{l}\text { Consumer food } \\
\text { knowledge }^{2}\end{array}$ & $\begin{array}{l}\text { Percentage of consumers who know } \\
\text { basic nutrition information (healthy } \\
\text { food, food safety etc.) }\end{array}$ & LSMS & $\mathrm{A}$ & NA & NA & NA & No \\
\hline & $\begin{array}{r}\text { National consumer } \\
\text { nutrition literacy }\end{array}$ & $\begin{array}{l}\text { Binary indicator that shows whether } \\
\text { national food-based dietary guide- } \\
\text { lines for a balanced and nutritious } \\
\text { diet are published or not }\end{array}$ & FAO & $\mathrm{A}$ & NA & A & A & No \\
\hline & $\begin{array}{l}\text { Income stream } \\
\text { diversity }\end{array}$ & $\begin{array}{l}\text { Percentage of households with more } \\
\text { than one income source }\end{array}$ & LSMS & $\mathrm{A}$ & A & A & A & No \\
\hline & $\begin{array}{l}\text { Policy environment } \\
\text { for stability }{ }^{3}\end{array}$ & $\begin{array}{l}\text { Indicators measuring governmental } \\
\text { commitment to ensure the } \\
\text { continuity of the proper functioning } \\
\text { of the food system in the event of } \\
\text { adverse shocks and trends. }\end{array}$ & $\begin{array}{c}\text { Government } \\
\text { web sites }\end{array}$ & $\mathrm{A}$ & A & $\mathrm{A}$ & A & Yes (DRR) \\
\hline & & $\begin{array}{l}\text { Presence of emergency response } \\
\text { plans/safety net programs: } \\
\text { Measures the presence of public } \\
\text { programs to intervene, when } \\
\text { needed, to facilitate access to food } \\
\text { by providing an additional income } \\
\text { to vulnerable people. }\end{array}$ & & & & & & \\
\hline & & $\begin{array}{l}\text { Presence of disaster recovery plans: } \\
\text { the presence of mechanisms and } \\
\text { allocation of resources for disaster } \\
\text { prevention and recovery (e.g., } \\
\text { presence of monitoring } \\
\text { mechanisms for changing climate } \\
\text { conditions and particular natural } \\
\text { hazard risks, such as drought) }\end{array}$ & & & & & & \\
\hline & & $\begin{array}{l}\text {-Existence of a policy plan for } \\
\text { overweight/obesity: indicator } \\
\text { whether or not a country has a fat } \\
\text { tax that is placed upon fattening } \\
\text { food to discourage unhealthy diets } \\
\text { and offset the economic costs of } \\
\text { obesity. }\end{array}$ & & & & & & \\
\hline Advocacy & $\begin{array}{l}\text { Consumer } \\
\quad \text { organizations }^{4}\end{array}$ & $\begin{array}{l}\text { Number of consumer organizations } \\
\text { that are active and present at a } \\
\text { national or regional level }\end{array}$ & $\begin{array}{l}\text { National } \\
\text { consumer } \\
\text { associations }\end{array}$ & A & A & A & A & No \\
\hline
\end{tabular}

Notes: A = Publicly available and NA = Currently not available; LSMS: This involves integrated household surveys that from part of the LSMS program or similar surveys. ${ }^{1}$ Available for women's time, and time available for housework for Vietnam; ${ }^{2}$ Nutritional knowledge of respondent mothers; ${ }^{3}$ Only data available on presence of social safety net programs and ${ }^{4}$ Consumers Association of Bangladesh, Ethiopian Consumers Protection Association, Consumer Awareness Organization for Nigeria, Vietnam Standards and Consumers Association 


\subsubsection{Food loss and waste management}

Food losses and waste play a key role in affecting global food and nutrition security by directly reducing the total food available for consumption and by indirectly increasing natural resource use (FAO, 2013). Food losses can occur along the value chain, but most food waste is recognized to occur after consumers purchase it (FAO, 2013; Lipinski et al., 2013). Preconsumer food losses are thought to be more prevalent in the food systems of developing countries (e.g. Delgado et al., 2017), and post-consumer food waste is considered to be higher in high-income countries (FAO, 2013; Gustafson et al., 2016). However, the extent and impact of food losses in developed countries should not be underestimated. While some stated that food loss or waste can be optimal in an economic sense (Bellemare et al., 2017) and recent rigorous evidence demonstrates that the rates of food loss and waste claimed by FAO (2011) are likely substantially overstated (Delgado et al., 2017; Ambler et al., 2018), food loss and waste management may constitute an important tool for improving food security and decreasing the pressure on food production (IFPRI, 2016; Jurgilevich et al., 2016).

Table 8 shows that data availability on those issues is limited, and the food loss and waste indicators from the SDGs and the data available do not overlap. While the SDGs propose to record the total percentage of food lost or wasted and the percentage of food waste that is recycled, data are only available on food losses at farm level. Note also that data collection methods used so far are not considered to be of high quality (Delgado et al., 2017). In measuring food loss, Delgado et al. (2017) emphasize the need to identify where food loss occurs in the food system along the various stage of the value chain and causes of food loss. They propose alternative methodologies that aim to reduce food loss measurement error and that allow to account for both quantitative and qualitative losses from the pre-harvest stage through product distribution, as well as discretionary losses among the processing, large distribution, and retail sectors.

\subsection{Metrics for measuring food system outcomes}

An optimized food system would meet consumers' food quality and safety demands, promote economic and sociocultural wellbeing of communities, reduce the pressure on aquatic and terrestrial ecosystems, and increase ecosystems capacity to respond to changes and shocks (Hinrichs, 2014; IPES, 2015, Béné et al., 2019b). Impacts of investments and food system interventions can be assessed more adequately when food system outcomes are measured well. In the present case, food system outcomes were classified into three categories: (i) diet, nutrition and health outcomes, (ii) socioeconomic outcomes, and (iii) environmental outcomes.

\subsubsection{Metrics for dietary, nutrition, and health outcomes}

Nutrition and health are among the most important food systems outcomes (Burchi et al., 2011; Padilla et al., 2015; Lartey et al. 2018). Health and nutrition status can be assessed using anthropometric measures, such as body-mass index for adults, stunting prevalence among children under 5 years old, or disease-related measures, such as anemia or the prevalence of diet-related non-communicable diseases, which are all available in the datasets that were reviewed here. These indicators are listed in Table 9 along with their degree of availability. Interestingly, while anthropometric data are available at microlevel as well as macrolevel, the availablity of diseaserelated measures is limited.

Diets provide a key link between the food system and health and nutrition status, as varied diets are essential to support individual physical and mental health. We focus on diet indicators that quantify two key attributes - diet quality and adequacy. Diet quality describes how well an individual's diet conforms to dietary recommendations that are often reflected in food based dietary guidelines (Alkerwi, 2014). The most commonly used assessment tool for dietary quality is the dietary diversity score. It refers to the consumption of a variety of desirable foods or food groups, reflecting both nutrient sufficiency (when measured at individual level) and economic ability to access a variety of foods (when measured at

Table 8 Indicators of the food loss and waste metric

\begin{tabular}{|c|c|c|c|c|c|c|c|}
\hline Indicators & Description & $\begin{array}{l}\text { Data } \\
\text { source }\end{array}$ & Bangladesh & Ethiopia & Nigeria & Vietnam & $\begin{array}{l}\text { Present } \\
\text { in SDG } \\
\text { indicators }\end{array}$ \\
\hline $\begin{array}{l}\text { Percentage of food } \\
\text { waste recycled }\end{array}$ & $\begin{array}{l}\text { Percentage of the total food waste that is recycled to recover } \\
\text { resources and/or to minimize negative environmental } \\
\text { effects of the waste }\end{array}$ & - & NA & NA & NA & NA & Yes \\
\hline $\begin{array}{l}\text { Food lost and wasted } \\
\text { in the food system }\end{array}$ & $\begin{array}{l}\text { Percentage of total food lost and wasted in the food system } \\
\text { from food production to consumption }\end{array}$ & - & NA & NA & NA & NA & Yes \\
\hline Food lost at farm level ${ }^{1}$ & Percentage of food lost at farm level & LSMS & A & A & A & NA & No \\
\hline
\end{tabular}

Notes: A = Publicly available and NA = Currently not available; LSMS: This involves integrated household surveys that from part of the LSMS program or similar surveys. ${ }^{1}$ Wastage of agriculture production for Bangladesh, quantity of production lost after harvest for Ethiopia and Nigeria 
Table 9 Indicators of the diet, nutrition and health outcomes metric

\begin{tabular}{|c|c|c|c|c|c|c|c|c|}
\hline $\begin{array}{l}\text { Metric } \\
\text { components }\end{array}$ & Indicators & Description & Data source & Bangladesh & Ethiopia & Nigeria & Vietnam & $\begin{array}{l}\text { Present in } \\
\text { SDG } \\
\text { indicators }\end{array}$ \\
\hline \multirow[t]{5}{*}{ Diet quality } & Food variety score & $\begin{array}{l}\text { Simple count of the different food } \\
\text { items consumed by household } \\
\text { members or an individual over } \\
\text { a given recall period (usually } \\
24 \mathrm{~h} \text {.). }\end{array}$ & LSMS & A & A & A & $\mathrm{A}$ & No \\
\hline & Dietary diversity score & $\begin{array}{l}\text { Measure of the number of unique } \\
\text { food groups consumed by } \\
\text { household members or an } \\
\text { individual over a reference } \\
\text { recall period. }\end{array}$ & LSMS & A & A & A & $\mathrm{A}$ & No \\
\hline & $\begin{array}{l}\text { Fruit and vegetable } \\
\text { consumption }\end{array}$ & $\begin{array}{l}\text { Average daily number of servings } \\
\text { of fruits and vegetables at } \\
\text { individual and/or household } \\
\text { level }\end{array}$ & LSMS & A & A & A & $\mathrm{A}$ & No \\
\hline & Healthy eating index ${ }^{1}$ & $\begin{array}{l}\text { Indicator of diet quality that } \\
\text { measures conformance to food } \\
\text { based dietary guidelines at } \\
\text { individual and/or household } \\
\text { level }\end{array}$ & $\begin{array}{l}\text { LSMS; FAO } \\
\text { (Dietary } \\
\text { guidelines) }\end{array}$ & $\mathrm{A}$ & A & $\mathrm{A}$ & $\mathrm{A}$ & Yes \\
\hline & $\begin{array}{l}\text { Consumption of } \\
\text { ultra-processed foods }\end{array}$ & $\begin{array}{l}\text { Consumption of processed meats, } \\
\text { saturated fat, cholesterol, } \\
\text { sodium and added sugar, which } \\
\text { are viewed as nutrients of } \\
\text { public health concern at } \\
\text { individual and/or household } \\
\text { level. }\end{array}$ & LSMS & A & A & A & A & No \\
\hline \multirow[t]{3}{*}{ Diet adequacy } & $\begin{array}{l}\text { Nutrient Rich Food } \\
\text { (NRF) Index }\end{array}$ & $\begin{array}{l}\text { Unweighted sum of percentage } \\
\text { daily values (DVs) for } 9 \text { nutri- } \\
\text { ents to encourage (protein; fi- } \\
\text { ber; vitamins A, C, and E; cal- } \\
\text { cium; iron; potassium; and } \\
\text { magnesium), minus the sum of } \\
\text { percentage maximum recom- } \\
\text { mended values (MRVs) for } 3 \\
\text { nutrients to limit limited (satu- } \\
\text { rated fat, added sugar, and } \\
\text { sodium), calculated per refer- } \\
\text { ence amount and capped at } \\
\text { 100\% DV (Drewnowski, } \\
\text { 2010). }\end{array}$ & LSMS & A & A & A & A & Yes \\
\hline & $\begin{array}{l}\text { Population share with } \\
\text { adequate nutrients }\end{array}$ & $\begin{array}{l}100 \text { minus the percentage of the } \\
\text { population with dietary intakes } \\
\text { of specified nutrients below the } \\
\text { Estimated Average } \\
\text { Requirement (EAR). }\end{array}$ & LSMS & A & $\mathrm{A}$ & A & $\mathrm{A}$ & Yes \\
\hline & $\begin{array}{r}\text { Mean probability of } \\
\text { adequacy (MPA) }\end{array}$ & $\begin{array}{l}\text { Average of probability of } \\
\text { adequacy (PA) of essential } \\
\text { nutrients, calculated based on } \\
\text { nutrient requirement distribu- } \\
\text { tions (EAR) and inter- and } \\
\text { intra-individual variation in in- } \\
\text { take. The MPA is calculated as } \\
\text { the sum of the PAs for all eval- } \\
\text { uated nutrients, divided by the } \\
\text { number of nutrients evaluated } \\
\text { and expressed as a percentage. } \\
\text { Alternatively, MPA can be } \\
\text { computed as the percentage of } \\
\text { population below the EAR of a } \\
\text { certain nutrient. }\end{array}$ & LSMS & $\mathrm{A}$ & $\mathrm{A}$ & A & $\mathrm{A}$ & Yes \\
\hline Food safety & $\begin{array}{l}\text { Access to safe potable } \\
\text { water }\end{array}$ & $\begin{array}{l}\text { The percentage of the population } \\
\text { with access to safe potable } \\
\text { water. }\end{array}$ & LSMS & A & A & A & A & Yes \\
\hline
\end{tabular}


Table 9 (continued)

\begin{tabular}{|c|c|c|c|c|c|c|c|c|}
\hline $\begin{array}{l}\text { Metric } \\
\text { components }\end{array}$ & Indicators & Description & Data source & Bangladesh & Ethiopia & Nigeria & Vietnam & $\begin{array}{l}\text { Present in } \\
\text { SDG } \\
\text { indicators }\end{array}$ \\
\hline & $\begin{array}{l}\text { Food safety regulatory } \\
\text { agency }^{2}\end{array}$ & $\begin{array}{l}\text { An indicator for whether a country } \\
\text { has a regulatory agency or body } \\
\text { to ensure the safety and health } \\
\text { of food }\end{array}$ & $\begin{array}{l}\text { National food } \\
\text { safety } \\
\text { authorities }\end{array}$ & A & A & A & $\mathrm{A}$ & No \\
\hline & $\begin{array}{l}\text { Incidence of food borne } \\
\text { diseases }\end{array}$ & $\begin{array}{l}\text { An indicator for proportion of } \\
\text { population affected by } \\
\text { foodborne diseases, including } \\
\text { enteric (intestinal) diseases, } \\
\text { chemicals and toxins, and par- } \\
\text { asitic diseases }\end{array}$ & LSMS & A & $\mathrm{A}$ & $\mathrm{A}$ & $\mathrm{A}$ & No \\
\hline \multirow[t]{6}{*}{$\begin{array}{l}\text { Health and } \\
\quad \text { nutrition } \\
\text { status }\end{array}$} & Height-for-age & $\begin{array}{l}\text { Prevalence of stunting (low } \\
\text { height-for-age, }<-2 \text { z-score) in } \\
\text { children under } 5 \text { years of age }\end{array}$ & DHS, FAOSTAT & A & $\mathrm{A}$ & $\mathrm{A}$ & $\mathrm{A}$ & Yes \\
\hline & Weight-for-height & $\begin{array}{l}\text { Prevalence of wasting (low } \\
\text { weight-for-height, }<-2 z \text {-score) } \\
\text { in children under } 5 \text { years of age }\end{array}$ & DHS, FAOSTAT & A & A & A & A & Yes \\
\hline & $\begin{array}{l}\text { Prevalence of } \\
\text { dietary-related non-- } \\
\text { communicable dis- } \\
\text { eases }\end{array}$ & $\begin{array}{l}\text { Indicator of the number of } \\
\text { dietary-related non-- } \\
\text { communicable disease affected } \\
\text { adult persons at a given time. It } \\
\text { is measured as the ratio of } \\
\text { number of cases of } \\
\text { dietary-related non-- } \\
\text { communicable diseases in the } \\
\text { population during a given peri- } \\
\text { od of time to number of persons } \\
\text { in that population at same time. }\end{array}$ & - & NA & NA & NA & NA & Yes \\
\hline & Prevalence of anemia & $\begin{array}{l}\text { The percentage of the population } \\
\text { or subgroups of the population } \\
\text { (e.g., children, women, etc.) } \\
\text { affected by anemia at given } \\
\text { period of time. }\end{array}$ & DHS, FAOSTAT & A & A & A & A & Yes \\
\hline & Body mass index (BMI) & $\begin{array}{l}\text { Indicator of appropriateness of the } \\
\text { ratio of weight to height } \\
\text { squared that is used to define } \\
\text { and screen for thinness }(<18.5) \text {, } \\
\text { overweight }(>25) \text { and obesity } \\
\text { (>30) for women and according } \\
\text { to age for children. }\end{array}$ & LSMS, DHS & A & $\mathrm{A}$ & $\mathrm{A}$ & $\mathrm{A}$ & No \\
\hline & $\begin{array}{l}\text { Prevalence of low birth } \\
\text { weight }\end{array}$ & $\begin{array}{l}\text { The percentage of newborns that } \\
\text { weigh less than } 2.5 \mathrm{~kg} \text { out of } \\
\text { the total number of live births in } \\
\text { the five (or two) years } \\
\text { preceding the point of } \\
\text { measurement in time. }\end{array}$ & FAOSTAT & $\mathrm{A}$ & NA & NA & $\mathrm{A}$ & No \\
\hline
\end{tabular}

Notes: A = Publicly available and NA = Currently not available; LSMS: This involves integrated household surveys that from part of the LSMS program or similar surveys. ${ }^{1}$ Bangladesh: http://www.fao.org/3/a-as880e.pdf; Ethiopia: http://extwprlegs1.fao.org/docs/pdf/eth157047.pdf; Nigeria: http://www. fao.org/3/a-as841e.pdf; and Vietnam: http://www.fao.org/3/a-as980o.pdf; ${ }^{2}$ Bangladesh Food Safety Authority, Food, Medicine and Health Care Administration and Control Authority of Ethiopia, National Agency for Food and Drug Administration and Control for Nigeria, and for Vietnam, three different ministries: the Ministry of Health $(\mathrm{MOH})$, the Ministry of Agriculture and Rural Development (MARD), and the Ministry of Industry and Trade (MOIT) are responsible for managing and implementing the Law on Food Safety (LoFS)

household level) (FAO, 2010; Global Panel, 2015). Maintaining diet quality involves both enhancing the role of healthy foods, such as fruits and vegetables, while limiting the consumption of unhealthy foods or food groups, such as ultraprocessed foods. Diet adequacy refers to the sufficient - not too little but also not too much - intake of energy and essential nutrients needed to fulfill nutritional requirements for optimal health appropriate to age, sex, disease status and physical activity for a healthy life (Castro-Quezada et al., 2014). Typically, the requirement for a given nutrient is defined as a lower (for heathy nutrients) or higher (for unhealthy nutrients) bound. Diet adequacy is assessed based on the 
comparison between the (estimated) nutrient requirement and the intake of a certain individual or population (CastroQuezada et al., 2014). Table 9 shows that the LSMS-type surveys, which typically include a seven day recall of food consumption, thus allows the construction of several household level diet quality and adequacy indicators.

Food safety is another key factor affecting nutrition and health outcomes of food systems. It includes all hazards and risks that make food consumption harmful or potentially harmful to the health of consumers. The primary focus of food safety efforts is the reduction of health hazards and risks related to microbial and food-borne pathogens (Hoffmann and Harder, 2012). Key indicators are the incidence of food borne diseases and toxins, and access to safe potable water-both available in the LSMS (Table 9) — and the presence of national regulatory agencies (available on the internet).

\subsubsection{Metrics for socioeconomic outcomes}

While dietary outcomes are the focus of this paper, other food system outcomes need due consideration. Food systems are the largest employer in LMICs (Chaudhary et al., 2018) and have the potential to be both economically viable and inclusive. Inclusive food systems could in turn provide sustainable livelihoods in the different sectors of the system, particularly for vulnerable groups like smallholders and women. In theory, food systems can also provide equitable access to food, thus improving global food security. Indicators for socioeconomic outcomes of food systems include measures of the economic and social wellbeing of the various players in the food system activities, including considerations of food security, gender equality, child labor and animal health and welfare. As detailed in Table 10, several indicators for measuring food systems' socioeconomic outcomes are present in the publicly available data.

\subsubsection{Metrics for environmental outcomes}

Food systems are also critically linked to the biophysical environment, which is a key source of crucial inputs (land, water, biodiversity and fossil fuels) and an important recipient of the waste stream and byproducts (Nesheim et al., 2015). Food systems can have significant environmental footprints (Prosperi et al., 2016; IPES 2016). Major environmental impacts of food systems include water pollution and depletion, soil degradation, desertification, biodiversity loss, and greenhouse gas (GHG) emissions contributing to climate change (Ericksen, 2008; Ingram, 2011; Vermeulen et al., 2012; FAO, 2011; Gustafson et al., 2016; Westhoek et al., 2016). Thus, sustainable food systems would be expected to achieve good nutrition and socioeconomic outcomes, while keeping the environmental impacts low enough so as not to transgress the planetary boundaries of biophysical processes and further destabilize environmental systems (Steffen et al., 2015; Béné et al. 2019a). Suitable indicators for environmental outcomes of the food system should therefore monitor changes in environmental conditions as reflected in the extent of resource consumption, biodiversity, harmful emissions, and natural resource management. Table 11 shows that aggregate information is available from AQUASTAT and FAOSTAT. Some indictors are also available at micro-level through LSMStype surveys. Overall, data availability is good, at least at the national level.

\section{Discussion and conclusion}

Using a "food system approach" to find ways to improve diets has become a key area of interest among policy makers and researchers. The approach appears particularly relevant for studying dietary changes, as diets are complex outcomes of food systems, involving feedback loops at multiple levels across multiple scales (Cash et al., 2006). However, for the approach to gain practical relevance, it is important to rely on a more comprehensive set of ready-to-use metrics and indicators that can characterize food systems, set meaningful policy goals, track progress, and evaluate potential impacts of innovations and interventions. Current metrics mostly focus on food system outcomes and do not cover all components of the food system.

The information from a comprehensive set of food system metrics could be used by decision-makers to identify leverage points for intervention and investments at both sub-national and national levels. More concretely, data on food system metrics can serve as input in policy discussions and, together with foresight analysis, feed into participatory scenario analysis to discuss trade-offs and synergies (Rutten et al., 2018). Food system metrics can also help in the identification of important policy knowledge questions. For example, food system indicators were used in an interactive process with key stakeholders in Ethiopia. The aim of this process was to characterize the food system and to develop priority research questions to support operationalizing food systems approaches to improve diets (Gebru et al., 2018). The resulting discussion paper is currently used by the National Information Platforms for Nutrition (NIPN) to help policymakers develop their knowledge questions further.

A subset of indicators could be used to develop food system countries profiles, allowing some rapid characterization of countries, comparative analyses across countries or even regions, and benchmarking and monitoring at global level, all of which would be extremely useful for both national and international decision-makers. Food system metrics can also help further the discussion between experts from diverse disciplines and backgrounds. This discussion is often frustrated by framing within distinctive disciplinary narratives (Bene 
Table 10 Indicators of the socioeconomic outcomes metric

\begin{tabular}{|c|c|c|c|c|c|c|c|c|}
\hline Metric components & Indicators & Description & Data source & Bangladesh & Ethiopia & Nigeria & Vietnam & $\begin{array}{l}\text { Present } \\
\text { in SDG } \\
\text { indicators }\end{array}$ \\
\hline Food security & $\begin{array}{l}\text { Household food } \\
\text { security }\end{array}$ & $\begin{array}{l}\text { Percentage of households that are } \\
\text { food secure based on the } \\
\text { household food insecurity } \\
\text { access scale (HFIAS), an index } \\
\text { of three key domains of } \\
\text { household access to food-- } \\
\text { perceptions of insufficient } \\
\text { quantity of food, perceptions of } \\
\text { inadequate quality of food and } \\
\text { uncertainty about whether the } \\
\text { food budget or supply is ade- } \\
\text { quate enough to meet the } \\
\text { household's basic require- } \\
\text { ments. }\end{array}$ & $\begin{array}{l}\text { LSMS/ } \\
\text { FAOSTAT }\end{array}$ & A & A & A & A & Yes \\
\hline \multirow[t]{8}{*}{$\begin{array}{l}\text { Food affordability } \\
\text { and availability }\end{array}$} & Poverty Index & $\begin{array}{l}\text { The proportion of the population } \\
\text { living below the "poverty } \\
\text { line", often defined as PPP } \\
\$ 1.90 \text { per person per day } \\
\text { threshold. }\end{array}$ & LSMS & $\mathrm{A}$ & $\mathrm{A}$ & A & $\mathrm{A}$ & Yes \\
\hline & $\begin{array}{l}\text { Income (in)equality } \\
\text { in a country or } \\
\text { region }{ }^{1}\end{array}$ & $\begin{array}{l}\text { Gini coefficient for distribution of } \\
\text { income, which has a value of } 0 \\
\text { for the case of perfect income } \\
\text { equality and } 1 \text { for the case of all } \\
\text { income earned by a single } \\
\text { individual. }\end{array}$ & World Bank & $\mathrm{A}$ & A & A & A & Yes \\
\hline & Food affordability & $\begin{array}{l}\text { The share of average annual } \\
\text { income spent on food (total } \\
\text { food expenditure/total income) }\end{array}$ & LSMS & $\mathrm{A}$ & A & A & A & No \\
\hline & $\begin{array}{r}\text { Food stressed } \\
\text { households }\end{array}$ & $\begin{array}{l}\text { Percentage of households } \\
\text { dedicating more than } 70 \% \text { of } \\
\text { their consumption } \\
\text { expenditures to food purchase }\end{array}$ & LSMS & $\mathrm{A}$ & $\mathrm{A}$ & A & $\mathrm{A}$ & No \\
\hline & $\begin{array}{l}\text { Distance to } \\
\text { supermarkets }\end{array}$ & $\begin{array}{l}\text { Estimated average distance to } \\
\text { three nearest supermarkets (an } \\
\text { indicator of the choices } \\
\text { available to consumers and the } \\
\text { level of competition among } \\
\text { stores) }\end{array}$ & LSMS & A & A & NA & A & No \\
\hline & Access to market & $\begin{array}{l}\text { Percentage of households with } \\
\text { access to more than one market } \\
\text { for food purchases }\end{array}$ & LSMS & A & A & A & A & No \\
\hline & $\begin{array}{l}\text { Healthy food } \\
\text { basket cost index }\end{array}$ & $\begin{array}{l}\text { Consists of a basket of food items } \\
\text { selected to meet adequate } \\
\text { nutritional requirements at the } \\
\text { lowest cost, and observations } \\
\text { of the costs of the basket over } \\
\text { time to assess trends in } \\
\text { affordability. The index would } \\
\text { monitor the affordability of a } \\
\text { nutritionally adequate diet. }\end{array}$ & LSMS & A & A & A & A & No \\
\hline & $\begin{array}{l}\text { Food consumer } \\
\text { price index } \\
\text { (FCPI) }\end{array}$ & $\begin{array}{l}\text { Price index (preferably } \\
\text { disaggregated nutritious vs. } \\
\text { less nutritious) based on the } \\
\text { average prices of cereals, fruit, } \\
\text { vegetables, fish and meat }\end{array}$ & $\begin{array}{l}\text { LSMS/ } \\
\text { FAOSTAT }\end{array}$ & A & A & A & A & No \\
\hline \multirow[t]{2}{*}{ Food utilization } & Access to power & $\begin{array}{l}\text { Percentage of households with } \\
\text { access to electricity for cooking }\end{array}$ & LSMS & A & A & A & A & Yes \\
\hline & Access to water & $\begin{array}{l}\text { Percentage of households with } \\
\text { access to safe drinking water }\end{array}$ & LSMS & A & A & $\mathrm{A}$ & A & Yes \\
\hline
\end{tabular}


Table 10 (continued)

\begin{tabular}{|c|c|c|c|c|c|c|c|c|}
\hline Metric components & Indicators & Description & Data source & Bangladesh & Ethiopia & Nigeria & Vietnam & $\begin{array}{l}\text { Present } \\
\text { in SDG } \\
\text { indicators }\end{array}$ \\
\hline & $\begin{array}{l}\text { Food cooling } \\
\text { facility }\end{array}$ & $\begin{array}{l}\text { Percentage of households } \\
\text { possessing enhanced } \\
\text { refrigeration systems }\end{array}$ & LSMS & A & A & A & A & No \\
\hline \multirow[t]{8}{*}{$\begin{array}{l}\text { Socioeconomic } \\
\text { welfare }\end{array}$} & Farm wage & $\begin{array}{l}\text { Average wage paid to } \\
\text { farmworkers in a country or } \\
\text { region }\end{array}$ & LSMS & $\mathrm{A}$ & A & $\mathrm{A}$ & A & Yes \\
\hline & Food sector wage & $\begin{array}{l}\text { Average wage paid to food } \\
\text { service, grocery and processing } \\
\text { workers in a country or region }\end{array}$ & LSMS & $\mathrm{A}$ & A & $\mathrm{A}$ & $\mathrm{A}$ & Yes \\
\hline & $\begin{array}{l}\text { Child labor in the } \\
\text { food system }\end{array}$ & $\begin{array}{l}\text { The percentage of children (ILO } \\
\text { convention ages } 6-17 \text { ) who are } \\
\text { employed in the different food } \\
\text { system sectors. }\end{array}$ & LSMS & A & A & $\mathrm{A}$ & A & Yes \\
\hline & Tenure security & $\begin{array}{l}\text { Extent of smallholders' tenure } \\
\text { security }\end{array}$ & LSMS & $\mathrm{A}$ & A & $\mathrm{A}$ & A & Yes \\
\hline & \multirow[t]{2}{*}{ Gender equality $^{2}$} & $\begin{array}{l}\text { a) Women's empowerment in } \\
\text { agriculture index (WEAI): } \\
\text { Index measuring women's } \\
\text { empowerment in five relevant } \\
\text { domains (role in production, } \\
\text { resources ownership, income } \\
\text { generation, leadership role and } \\
\text { time allocation) of women in } \\
\text { their households (Alkire et al. } \\
\text { 2013) }\end{array}$ & LSMS/ DHS & $\mathrm{A}$ & A & $\mathrm{A}$ & A & Yes \\
\hline & & $\begin{array}{l}\text { b) The Global Gender Gap Index } \\
\text { (GGGI): an index measuring } \\
\text { the extent of gender disparity } \\
\text { based on four indicators- } \\
\text { economic participation and } \\
\text { opportunity, educational } \\
\text { attainment, health and survival, } \\
\text { and political empowerment } \\
\text { (Gustafson et al., 2016). }\end{array}$ & LSMS/ DHS & $\mathrm{A}$ & A & A & A & Yes \\
\hline & Household income & $\begin{array}{l}\text { Average household income of } \\
\text { households who make their } \\
\text { livelihood from food system } \\
\text { activities }\end{array}$ & LSMS & A & A & A & A & No \\
\hline & $\begin{array}{l}\text { Animal health and } \\
\text { welfare }^{3}\end{array}$ & $\begin{array}{l}\text { a) Animal health and welfare } \\
\text { legal framework: an indicator } \\
\text { for whether a country has put } \\
\text { in place the basic legal } \\
\text { frameworks needed to protect } \\
\text { animal health and welfare; } \\
\text { b) Animal Protection Index } \\
\text { (API): ranking of countries } \\
\text { based on their commitment to } \\
\text { animal protection, which gives } \\
\text { letter grades to ranked } \\
\text { countries ranging from a high } \\
\text { of "A" to a low of "G" (World } \\
\text { Society for the Protection of } \\
\text { Animals). }\end{array}$ & $\begin{array}{l}\text { World Animal } \\
\text { Protection }\end{array}$ & NA & $\mathrm{A}$ & $\mathrm{A}$ & $\mathrm{A}$ & No \\
\hline
\end{tabular}

Notes: A = Publicly available and NA = Currently not available; LSMS: This involves integrated household surveys that from part of the LSMS program or similar surveys. ${ }^{1}$ https://data.worldbank.org/indicator/SI.POV.GINI?locations=BD-ET-NG-VN; ${ }^{2}$ For Ethiopia and Nigeria, decisions made by husband or wife or both in household decisions; ${ }^{3}$ https://api.worldanimalprotection.org/\# 
Table 11 Indicators of the environmental outcomes metric

\begin{tabular}{|c|c|c|c|c|c|c|c|c|}
\hline Metric components & Indicators & Description & Data source & Bangladesh & Ethiopia & Nigeria & Vietnam & $\begin{array}{l}\text { Present } \\
\text { in SDG } \\
\text { indicators }\end{array}$ \\
\hline \multirow[t]{7}{*}{$\begin{array}{l}\text { Resource } \\
\quad \text { consumption }\end{array}$} & $\begin{array}{l}\text { Capture fish } \\
\text { consumption }\end{array}$ & $\begin{array}{l}\text { Percentage of total seafood } \\
\text { production accounted for by } \\
\text { capture fishery }\end{array}$ & LSMS & $\mathrm{A}$ & NA & A & A & Yes \\
\hline & $\begin{array}{r}\text { Net freshwater } \\
\text { withdrawals }\end{array}$ & $\begin{array}{l}\text { Total annual food system net } \\
\text { freshwater withdrawals from } \\
\text { aquifers ( } \mathrm{m}^{3} \text { freshwater } \\
\text { consumption per year) in a } \\
\text { country or region. }\end{array}$ & AQUASTAT & NA & A & NA & NA & Yes \\
\hline & $\begin{array}{l}\text { Water productivity in } \\
\text { agriculture }\end{array}$ & $\begin{array}{l}\text { The value of agricultural } \\
\text { production divided by the } \\
\text { volume of water withdrawn for } \\
\text { agriculture (does not take into } \\
\text { account the use of rainfall) }\end{array}$ & AQUASTAT & NA & A & NA & NA & No \\
\hline & Land use & $\begin{array}{l}\text { Total annual food system land use } \\
\left(\mathrm{m}^{2} \text { per year), regardless of the }\right. \\
\text { purpose of the land use } \\
\text { (cultivation, grazing, etc.). }\end{array}$ & FAOSTAT & A & A & A & A & No \\
\hline & $\begin{array}{l}\text { Non-renewable energy } \\
\text { use }\end{array}$ & $\begin{array}{l}\text { Total annual } \\
\text { agricultural non-renewable en- } \\
\text { ergy use (Megajoules (MJ) per } \\
\text { year). }\end{array}$ & FAOSTAT & $\mathrm{A}$ & $\mathrm{A}$ & $\mathrm{A}$ & A & No \\
\hline & $\begin{array}{l}\text { Agricultural water } \\
\text { withdrawal }\end{array}$ & $\begin{array}{l}\text { Annual quantity of self-supplied } \\
\text { water withdrawal for irrigation, } \\
\text { livestock and aquaculture pur- } \\
\text { poses. }\end{array}$ & FAOSTAT & $\mathrm{A}$ & A & NA & A & No \\
\hline & $\begin{array}{l}\text { Agricultural irrigated } \\
\text { land }\end{array}$ & $\begin{array}{l}\text { Agricultural land purposely } \\
\text { provided with water, including } \\
\text { land irrigated by controlled } \\
\text { flooding, as a percentage of } \\
\text { total agricultural land. }\end{array}$ & LSMS & $\mathrm{A}$ & $\mathrm{A}$ & A & A & No \\
\hline \multirow[t]{3}{*}{ Biodiversity } & Biodiversity loss & $\begin{array}{l}\text { Plant and/or animal species that } \\
\text { are near to extinct or endan- } \\
\text { gered to extinction }\end{array}$ & FAOSTAT & $\mathrm{A}$ & $\mathrm{A}$ & A & $\mathrm{A}$ & Yes \\
\hline & Crop varieties & $\begin{array}{l}\text { Number of crops accounted for } \\
\text { top } 75 \% \text { of the total land } \\
\text { cultivated in a region or a } \\
\text { country }\end{array}$ & FAOSTAT & A & A & A & A & No \\
\hline & Species diversity & $\begin{array}{l}\text { The diversity of species of crops } \\
\text { and animals living in } \\
\text { agricultural, forestry and } \\
\text { fisheries ecosystems }\end{array}$ & FAOSTAT & A & A & $\mathrm{A}$ & A & No \\
\hline Emissions & $\begin{array}{l}\text { Greenhouse gas } \\
\text { (GHG) emissions }\end{array}$ & $\begin{array}{l}\text { Total annual food system } \mathrm{GHG} \\
\text { emissions }\left(\mathrm{kg} \mathrm{CO}_{2} \text { equivalent }\right. \\
\left.\text { per year: } \mathrm{CO}_{2}, \mathrm{CH}_{4}, \mathrm{~N}_{2} \mathrm{O}\right) \text { in a } \\
\text { country or region. }\end{array}$ & FAOSTAT & A & A & A & A & Yes \\
\hline \multirow[t]{2}{*}{$\begin{array}{l}\text { Resource } \\
\quad \text { management }\end{array}$} & $\begin{array}{l}\text { Water infrastructure } \\
\text { maintenance }^{1}\end{array}$ & $\begin{array}{l}\text { Frequency of control and } \\
\text { maintenance work on water } \\
\text { system (e.g., dams) }\end{array}$ & LSMS & $\mathrm{A}$ & $\mathrm{A}$ & $\mathrm{A}$ & $\mathrm{A}$ & Yes \\
\hline & Soil conservation & $\begin{array}{l}\text { Percentage of farmer producers } \\
\text { implementing soil } \\
\text { conservation measures }\end{array}$ & LSMS & NA & A & A & NA & Yes \\
\hline
\end{tabular}

Notes: A = Directly available and NA = Currently not available; LSMS: This involves integrated household surveys that from part of the LSMS program or similar surveys. ${ }^{1}$ Irrigation (channel maintenance) per hour costs are available 
et al., 2019b). Concrete data on a broad set of food system metrics can help identify these narratives and test whether they are supported by or not conflicting with the data.

In this paper, we propose a comprehensive set of metrics that can enable the measurement of food systems across all relevant domains and dimensions. Building on previous work, we present a conceptual framework of food systems and use it to systematically identify relevant metrics and indicators based on data availability in LMICS. To assure the practical applicability of the metrics and allow for inter-country comparisons, we select indicators present in datasets that are available in LMICS. We prioritize indicators that overlap with the SDG indicators, although the latter do not cover all aspects of the food system. We apply our approach to four countries. This allows us not only to show commonalities in data availability, but also reveals differences between similar datasets.

Key datasets are the LSMS and FAOSTAT, and for health and nutrition indicators, the DHS. While the existence of ready-to-use aggregate indicators from datasets like FAOSTAT is helpful for quick scans of some aspects of food systems, the availability of raw micro-level data from the LSMS has other advantages. The four study countries are large countries with high diversity in terms of agroecology, geography, rural-urban gradients, population, and multiple food sub-systems (Gebru et al., 2018; Raneri et al., 2019). As such, data collected at national scale tend to mask spatial and sectoral differences coming from these diversities within the countries. In addition, many indicators, such as food safety, diet diversity, and food losses and waste, can in theory be measured at local or sub-group scale and traced throughout the food system. Micro-level datasets allow doing so, thus potentially providing information about distributional implications and leverage points for interventions.

Key advantages of the LSMS and DHS are that they are nationally representative and available for multiple countries. The latter, however, does not automatically mean that the metrics are comparable between countries. Statistical capacities are dire in many LMICs, particularly in Africa (Jerven, 2013). The surveys used for data collection in the different countries were designed and conducted by various actors. For example, the LSMS surveys in Ethiopia and Nigeria were supported by the World Bank. The Bangladesh Integrated Household Survey (BIHS) was conducted by the International Food Policy Research Institute (IFPRI) under the auspices of the Feed the Future (FTF) program. The other national-level surveys were conducted by the statistical authorities or relevant ministries of the respective countries. The surveys were not conducted in standardized and harmonized ways, and there are likely to be inconsistency in guidelines for the data collection, which can impair the comparability of the metrics across the countries. The datasets across the different countries also vary in terms of quality and their coverage in the rural-urban gradient. For example, the BIHS covers rural areas only, while the other data sets cover both rural and urban areas. In addition, not all selected indicators are available for all countries. With these considerations, the metrics based on these datasets remain greatly important to support evidence-based decision making in the food systems of the respective countries.

We find that public data are available on food system drivers and outcomes, and on some of the activities, notably production and consumption. Data on food processing, food distribution and marketing, and food loss and waste appear less complete and thus require additional data collection efforts. With such data limitations, it would be difficult to carry out food system analyses that adequately address the complexity and trade-offs/synergies of the food system using the metrics currently available. Specifically, there is a risk that food system activities with missing data would largely be ignored in policy analyses and discussions, which could result in missing appropriate problem solutions or causing unwanted side effects.

Improving the accuracy and usefulness of food systems metrics requires setting widely accepted norms and standards for data collection, collecting data for important metrics which are not often covered in traditional surveys, systematic analysis and synthesis of existing datasets, promoting the principle of open data access, and improving capacity to analyse and use data at all levels. To increase their relevance for policy and practice, food system metrics should allow disaggregated analyses at multiple levels across different scales, including different social groups, regions and local levels. Data on seasonal patterns and their impact on food consumption, and on nutritional intake of macro- and micronutrients across time and space (within- and between-countries) are likely to be important for policymakers and practitioners.

With only minor additional investments, LSMS-type surveys could be extended to cover much of the required data. When individual indicators are not available for all countries, and this can easily be solved by including the relevant questions in the follow-up surveys for the relevant countries. In next data collection efforts, new modules could be added. In contrast to household surveys under the LSMS program, the community questionnaire of the Bangladesh Integrated Household Survey (BIHS) covers information on quality and accessibility of the road network, food warehousing and cold storage, all of which could be included in LSMS surveys relatively easily. The BIHS survey also includes valuable questions on nutrition knowledge in the household questionnaire. Food processing is a relatively new concern with limited coverage in all current surveys. The food expenditures sections contain only highly aggregate categories for processed foods that are less suitable for assessing their contribution to diets and nutrition. Some careful recategorization could solve this problem. The consumption questionnaire could also be extended to include food waste at the consumer level. 
For some indicators lacking data, such as food losses in the value chain and food distribution indicators with above-local relevance, targeted data collection efforts are needed. As there is overlap with the SDG indicators, part of the collected data could serve a dual purpose: both improving the description and monitoring of food systems, and to track progress towards attaining the SDGs.

Acknowledgments We thank Thom Achterbosch, Namukolo Covic, Ellis Hoffland, Gina Kennedy, John McDermott, Peter Oosterveer, Roseline Remans, Ruerd Ruben, Maja Slingerland and Laura Trijsburg for their valuable inputs.

\section{Compliance with ethical standards}

Conflict of interest The authors state that they have no conflict of interests.

Open Access This article is licensed under a Creative Commons Attribution 4.0 International License, which permits use, sharing, adaptation, distribution and reproduction in any medium or format, as long as you give appropriate credit to the original author(s) and the source, provide a link to the Creative Commons licence, and indicate if changes were made. The images or other third party material in this article are included in the article's Creative Commons licence, unless indicated otherwise in a credit line to the material. If material is not included in the article's Creative Commons licence and your intended use is not permitted by statutory regulation or exceeds the permitted use, you will need to obtain permission directly from the copyright holder. To view a copy of this licence, visit http://creativecommons.org/licenses/by/4.0/.

\section{References}

Acharya, T., Fanzo, J., Gustafson, D., Ingram, J., Schneeman, B., Allen, L., Boote, K., Drewnowski, A., Ewert, F. \& Hall, S. (2014). Assessing sustainable nutrition security: The role of food systems. Center for Integrated Modeling of sustainable agriculture and nutrition security. Washington, DC.

Alkerwi, A. (2014). Diet quality concept. Nutrition, 30(6), 613-618.

Allen, S., \& de Brauw, A. (2018). Nutrition sensitive value chains: Theory, progress, and open questions. Global Food Security, 16, $22-28$.

Allen, T., \& Prosperi, P. (2014). Metrics of sustainable diets and food systems. Montpellier: Workshop Report. Bioversity International \& CIHEAM-IAMM.

Allen, T., \& Prosperi, P. (2016). Modeling sustainable food systems. Environmental Management, 57(5), 956-975.

Ambler, K., de Brauw, A., \& Godlonton, S. (2018). Measuring postharvest losses at the farm level in Malawi. Australian Journal of Agricultural and Resource Economics, 62(1), 139-160.

Becker, N. (2017). External costs of food production: Environmental and human health costs of Pest management. Chapter 16 in Environmental Pest Management: Challenges for Agronomists, Ecologists, Economists, and Policymakers, M. Coll and E. Wajnberg, eds. Wiley.

Bellemare, M. F., Cakir, M., Peterson, H. H., Novak, L., \& Rudi, J. (2017). On the measurement of food waste. American journal of agricultural economics, 99(5), 1148-1158.

Béné, C., Prager, S. D., Achicanoy, H. A. E., Alvarez, T. P., Lamotte, L., Bonilla, C. C., \& Mapes, B. R. (2019a).
Global map and indicators of food system sustainability. Scientific Data Nature, 6, 279.

Béné, C., Oosterveer, P., Lamotte, L., Brouwer, I. D., de Haan, S., Prager, S. D., Talsma, E. F., \& Khoury, C. K. (2019b). When food systems meet sustainability: Current narratives and implications for actions. World Development, 113, 116-130.

Béné, C., Prager, S. D., Achicanoy, H. A. E., Alvarez, T. P., Lamotte, L., Bonilla, C. C., \& Mapes, B. R. (2019c). Understanding food systems drivers: A critical review of the literature. Global Food Security, 23, 149-159.

Burchi, F., Fanzo, J., \& Frison, E. (2011). The role of food and nutrition system approaches in tackling hidden hunger. International Journal of Environmental Research and Public Health, 8, 358-373.

Caron, P. Ferrero y de Loma-Osorio G., Nabarro D., Hainzelin, E., et al. (2018). Food systems for sustainable development: Proposals for a profound four-part transformation. Agronomy for Sustainable Development 38: 41.

Cash, D. W., Adger, W., Berkes, F., Garden, P., Lebel, L., Olsson, P., Pritchard, L., \& Young, O. (2006). Scale and cross-scale dynamics: Governance and information in a multilevel world. Ecology and Society, 11(2), 8 .

Castro-Quezada, I., Román-Viñas, B., \& Serra-Majem, L. (2014). The Mediterranean diet and nutritional adequacy: A review. Nutrients, 6 , 231-248.

Chaboud, G., \& Daviron, B. (2017). Food losses and waste: Navigating the inconsistencies. Global Food Security, 12, 1-7.

Chaudhary, A., Gustafson, D., \& Mathys, A. (2018). Multi-indicator sustainability assessment of global food systems. Nature Communications, 9, 848 .

Delgado, L., Schuster, M. \& Torero, M. (2017). Reality of food losses: A new measurement methodology. Working Paper, International Food Policy Research Institute, Washington, DC.

Dentoni, D., Waddell, S., \& Waddock, S. (2017). Pathways of transformation in global food and agricultural systems: Implications from a large systems change theory perspective. Current Opinion on Environmental Sustainability, 29, 8-13.

Eakin, H., Connors, J. P., Wharton, C., Bertmann, F., Xiong, A., \& Stoltzfus, J. (2016). Identifying attributes of food system sustainability: Emerging themes and consensus. Agriculture and Human Values, 34, 757-773. https://doi.org/10.1007/s10460-016-9754-8.

Ericksen, P. J. (2008). Conceptualizing food Systems for Global Environmental Change Research. Global Environmental Change, $18,234-245$.

FAO. (2010). Guidelines for measuring household and individual dietary diversity. Rome: Food and Agriculture Organization.

FAO. (2011). Global food losses and food waste -extent, causes and prevention. Rome: Food and Agriculture Organization.

FAO. (2013). Food wastage footprint - impacts on natural resources. Food and Agriculture Organization, Rome: Technical Report.

FAO. (2016). Compendium of indicators for nutrition-sensitive agriculture. Rome: Food and Agriculture Organization of the United Nations.

Fiorella, K. J., Chen, R. L., Milner, E. M., \& Fernald, L. C. (2016). Agricultural interventions for improved nutrition: A review of livelihood and environmental dimensions. Global Food Security, 8, 39 47.

Foran, T., Butler, J. R. A., Williams, L. J., Wanjura, W. J., Hall, A., \& Carter, L. (2014). Taking complexity in food systems seriously: An interdisciplinary analysis. World Development, 61, 85-101.

Gebru, M., Remans, R., Brouwer, I., Baye, K., Melesse, M. B. , Covic, N., Habtamu, F., Abay, A.H., Hailu, T., Hirvonen, K., Kassaye, T., Kennedy, G., Lachat, C., Lemma, F., McDermott, J., Minten, B, Moges, T., Reta, F., Tadesse, E., Taye, T., Truebswasser, U., and Van den Berg, M. (2018). Food Systems for Healthier Diets in Ethiopia: Toward a Research Agenda. IFPRI Discussion Paper 01720 . 
Global Panel (2015). Improved metrics and data are needed for effective food system policies in the Post-2015 era. Technical brief no. 2. Global Panel on Agriculture and Food Systems for Nutrition, London, UK.

Grant, M. (2015). A food systems approach for food and nutrition security. Sight and Life 29(1).

Gustafson, D., Gutman, A., Leet, W., Drewnowski, A., Fanzo, J. \& Ingram, J. (2016). Seven food system metrics of sustainable nutrition security. Sustainability $8(196)$.

Hawkes, C., Friel, S., Lobstein, T., \& Lang, T. (2012). Linking agricultural policies with obesity and diet-related non-communicable diseases: A new perspective for a globalizing world. Food Policy, 37(3), 343-353.

Hinrichs, C. C. (2014). Transitions to sustainability: A change in thinking about food systems change? Agriculture and Human Values, 31, $143-155$.

Hoffmann, S. \& Harder, W. (2012). Food safety and risk governance in globalized markets. Health Matrix 20 (1).

IFPRI (2016). Global nutrition report 2016: From promise to impact ending malnutrition by 2030 . International food policy research institute, Washington, DC.

Imamura, F., Micha, R., Khatibzadeh, S., Fahimi, S., Shi, P., Powles, J., \& Mozaff, D. (2015). Dietary quality among men and women in 187 countries in 1990 and 2010: A systematic assessment. The Lancet Global Health, 3(3), e132-e142.

Ingram, J. (2009). Food system concepts. In ESF/COST Forward Look on European Food Systems in a Changing World, European Science Foundation, PP. 9-13.

Ingram, J. (2011). A food systems approach to researching food security and its interactions with global environmental change. Food Security, 3, 417-431.

IPES (2015). The new science of sustainable food systems: Overcoming barriers to food systems reform. International panel of experts on sustainable food systems (IPES).

IPES (2016). From uniformity to diversity: A paradigm shift from industrial agriculture to diversified Agroecological systems. International Panel of Experts on Sustainable Food systems, $96 \mathrm{p}$.

Jerven, M. (2013). Poor numbers. How we are misled by African development statistics and what to do about it. Ithaca, NY: Cornell University Press.

Jones, A. D., Ngure, F. M., Pelto, G., \& Young, S. L. (2013). What are we assessing when we measure food security? A compendium and review of current metrics. Advances in Nutrition: An International Review Journal, 4(5), 481-505.

Jurgilevich, A., Birge, T., Kentala-Lehtonen, J., Korhonen-Kurki, K., Pietikäinen, J., Saikku, L. \& Schösler, H. (2016).Transition towards circular economy in the food system. Sustainability 8(69).

Just, D. R., \& Gabrielyan, G. (2016). Why behavioral economics matters to global food policy. Global Food Security, 11, 26-33.

Lartey, A., Meerman, J., \& Wijesinha-Bettoni, R. (2018). Why food system transformation is essential and how nutrition scientists can contribute. Annals of Nutrition and Metabolism, 72, 193-201.

Lehtonen, M., Sébastien, L., \& Bauler, T. (2016). The multiple roles of sustainability indicators in informational governance: Between intended use and unanticipated influence. Current Opinion in Environmental Sustainability, 18, 1-9.

Lipinski, B., Hanson, C., Lomax, J., Kitinoja, L., Waite, R. \& Searchinger, T. (2013). Reducing food loss and waste. Working Paper, World Resources Institute, Washington DC.

McDermott, J., Johnson, N., Kadiyala, S., Kennedy, G., \& Wyatt, A. J. (2015). Agricultural research for nutrition outcomes: Rethinking the agenda. Food Security, 7(3), 593-607.

Miller, D. D., \& Welch, R. M. (2013). Food system strategies for preventing micronutrient malnutrition. Food Policy, 42, 115-128.
Nesheim, M. C., Oria, M., \& Yih, P. T. (2015). A framework for assessing effects of the food system. Washington DC: The National Academies Press.

Padilla, M., Prosperi, P., Cogill, B., Allen, T. \& Peri, I. (2015). Metrics of sustainable diets and food systems insights from a multi-institutional research partnership. Watch letter no. 32. International Center for Advanced Mediterranean Agronomic Studies (CIHEAM).

Pingali, P. (2007). Westernization of Asian diets and the transformation of food systems: Implications for research and policy. Food Policy, 32(3), 281-298.

Pinstrup-Andersen, P., Watson, D., Frandsen, S., Kuyvenhoven, A., \& Von Braun, J. (2011). Food policy for developing countries: The role of government in global, national, and local food systems. Ithaca; London: Cornell University Press.

Popkin, B. M. (2014). Nutrition, agriculture and the global food system in low and middle income countries. Food Policy, 47, 91-96.

Prosperi, P., Allen, T., Padilla, M., Peri, I. \& Cogill, B. (2014). Sustainability and Food \& Nutrition Security: A vulnerability assessment framework for the Mediterranean region. SAGE Open: $1-15$.

Prosperi, P., Allen, T., Cogill, B., Padilla, M., \& Peri, I. (2016). Towards metrics of sustainable food systems: A review of the resilience and vulnerability literature. Environment Systems and Decisions, 36(1), 3-19.

Raneri, J. E., Kennedy, G., Nguyen, T., Wertheim-Heck, S., Do, H., de Haan, S. et al. (2019). Determining key research areas for healthier diets and sustainable food Systems in Viet Nam. IFPRI discussion paper 01872 .

Rutten, M., Achterbosch, T. J., De Boer, I. J., Cuaresma, J. C., Geleijnse, J. M., Havlík, P., et al. (2018). Metrics, models and foresight for European sustainable food and nutrition security: The vision of the SUSFANS project. Agricultural Systems, 163, 45-57.

Sobal, J., Kahn, L. K., \& Bisogni, C. (1998). A conceptual model of the food and nutrition system. Social Science \& Medicine, 47, 853-863.

Springmann, M., Godfray, H. C. J., Rayner, M., \& Scarborough, P. (2016). Analysis and valuation of the health and climate change cobenefits of dietary change. Proceedings of the National Academy of Sciences, 113, 4146-4151.

Steffen, W., Richardson, K., Rockstrom, J., Cornell, S. E., Fetzer, I., Bennett, E. M., Biggs, R., Carpenter, S. R., de Vries, W., de Wit, C. A., Folke, C., Gerten, D., Heinke, J., Mace, G. M., Persson, L. M., Ramanathan, V., Reyers, B., \& Sorlin, S. (2015). Planetary boundaries: Guiding human development on a changing planet. Science, 347, 1259855.

Sundaram, J. K. (2014). Tackling the nutrition challenge: A food systems approach. Development, 57(2), 141-146.

Tilman, D., \& Clark, M. (2014). Global diets link environmental sustainability and human health. Nature, 515, 518-522.

Turner, C., Aggarwal, A., Walls, H., Herforth, A., Drewnowski, A., Coates, J., Kalamatianou, S., \& Kadiyala, S. (2018). Concepts and critical perspectives for food environment research: A global framework with implications for action in low- and middle-income countries. Global Food Security, 18, 93-101.

Van Dooren, C., Marinussen, M., Blonk, H., Aiking, H., \& Vellinga, P. (2014). Exploring dietary guidelines based on ecological and nutritional values: A comparison of six dietary patterns. Food Policy, 44, 36-46.

Vermeulen, S. J., Campbell, B. M., \& Ingram, J. (2012). Climate change and food systems. Annual Review of Energy and the Environment, $37,195-222$.

Westhoek, H, Ingram J., Van Berkum, S., Özay, L., \& Hajer, M. (2016). Food systems and natural resources. A report of the working group on food Systems of the International Resource Panel. 164 p. UNEP Nairobi. 
Wirsenius, S., Azar, C., \& Berndes, G. (2010). How much land is needed for global food production under scenarios of dietary changes and livestock productivity increases in 2030? Agricultural Systems, 103, 621-638.

Zurek, M. et al. (2017). Sustainability metrics for the EU food system: A review across economic, environmental and social considerations. SUSFANS Project, Deliverable No. 1.3.

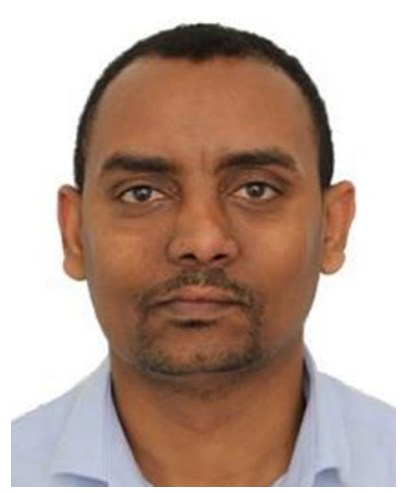

Mequanint B. Melesse is a Scientist, Development Economist, at International Crops Research Institute for the Semi-Arid Tropics (ICRISAT) in the Innovation Systems for the Drylands Program, Markets, Institutions, Nutrition \& Diversity, based in Nairobi, Kenya. He holds a PhD in development economics from Wageningen University in 2015. His main research interests are in development economics, and behavioral and experimental economics, with a focus on agricultural and rural development. His specific thematic research interests include impact analysis, drivers of economic development \& behavioral changes, food and nutrition security, women's empowerment, as well as institutional economics. His research works are typically based on original primary data collected from developing countries, and use a variety of methods, including randomized evaluations, lab-in-the-field behavioral experiments, quasi-experimental and nonexperimental approaches. He has published papers widely in a number of well-established peer reviewed international journals, including Agricultural Economics, Journal of Economic Behavior \& Organization, World Development, and Journal of Development Studies. He has presented his research findings at several international conferences, as well as workshops and regional networks. Currently, he is working on several projects and programs focusing on technology need assessment and adoption, impact evaluation, agricultural value chains, poverty and nutrition. He is also affiliated with the Development Economics Group, Wageningen University.

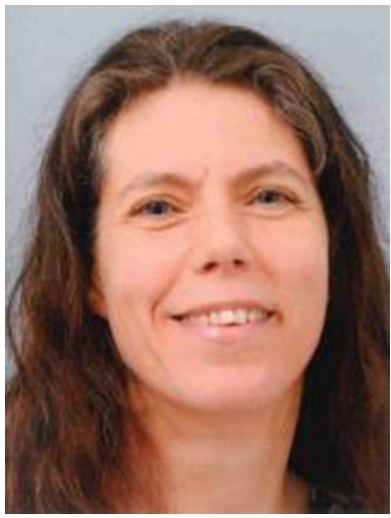

Dr. Marrit van den Berg is associate professor at the Development Economics group of Wageningen University. She has obtained her PhD from that same university in 2001, after which she worked for a couple of years as researcher at the Development Research Institute of Tilburg University before returning to Wageningen. As part of her current position, she coleads the research cluster on Food System Innovations within the Food Systems for Healthier Diets Flagship of the CGIAR research program Agriculture for Nutrition and Health (https://a4nh.cgiar.org/our-research/flagship-1/). The cluster tests concrete agri-food value chains innovations and interventions for improving diet quality and diversity so that stakeholders - investors, civil society, policymakers - consider healthier diets in processes related to food systems. Among other things, Dr. Van den Berg's food system innovations work involves the supervision of four $\mathrm{PhD}$ students, each studying innovations in a different context: Bangladesh, Ethiopia, Mexico and Vietnam. Many, but not all, of the innovations aim at stimulating the consumption of fruits and vegetables and are targeted at consumers and their food environment. Examples are videobased behaviour change communication in Addis Abeba (Ethiopia), promotion of fruits and vegetable consumption among school children around Hanoi (Vietnam) and in Nuevo Leon (Mexico). Core methods used are behavioural experiments and RCTs. For this work, she also got awarded a grant within the Senior Expert Program of the Dutch Science Foundation (NWO). Dr. Van den Berg also researches smallholder farmers, the impact of commercialization on food and nutrition security and technology adoption. She teaches development economics and quantitative methods for fieldwork.

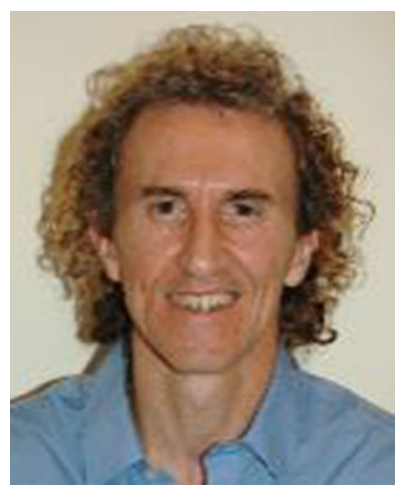

Christophe Béné is Senior Policy Advisor at the International Center for Tropical Agriculture (CIAT) -one of the 16 centers of the Consultative Group on International Agricultural Research (CGIAR)based in Cali, Colombia. He holds a $\mathrm{PhD}$ in Environment and Life Sciences from the University of Paris 6, and a post-graduate Diploma in Development Economics from the School of Development Studies at the University of East Anglia (UK). He has $15+$ years of experience in inter-disciplinary research and advisory work focusing on poverty alleviation, resilience, and food security. $\mathrm{He}$ currently co-leads the policy analysis cluster of the CGIAR flagship program "Food System for Healthier Diet".

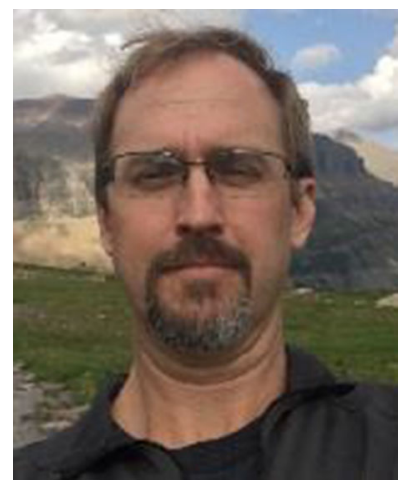

Alan de Brauw is a Senior Research Fellow in the Markets, Trade and Institutions Division of the International Food Policy Research Institute (IFPRI). He has a Ph.D. in Agricultural and Resource Economics from the University of California at Davis, and prior to joining IFPRI he was an Assistant Professor of Economics at Williams College. His research agenda has focused on understanding impacts of agricultural interventions, including those working to improve nutritional status among beneficiaries, the role of women in the rural economy of developing countries, and the effects of migration on source households. Much of his research is derived from primary survey work, usually designed for evaluative purposes; he has helped design, plan, and conduct multi-topic household surveys, mainly in rural areas, in Bangladesh, 
Brazil, Cambodia, China, El Salvador, Ethiopia, Ghana, Honduras, Mozambique, Malawi, Senegal, and Vietnam. His research is published widely in development economics, agricultural economics, and nutrition journals including the Journal of Human Resources, Journal of Development Economics, World Bank Economic Review, the American Journal of Agricultural Economics, and the Journal of Nutrition, and currently serves as an Associate Editor of the American Journal of Agricultural Economics.

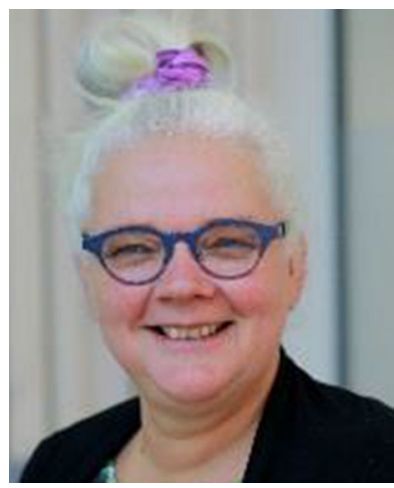

Inge D. Brouwer (Ph.D.) is Associate Professor at the Division of Human Nutrition, Wageningen University. Her research focuses on improvement of dietary quality of (young) women and children, in low and middle income countries through agricultural or food systems approaches, with special emphasis on reducing the burden of undernutrition, micronutrient deficiencies and overnutrition. Dr. Brouwer has acquired many research funds, from national funding programmes, from EU FP6 and FP7 Framework Programmes as well as from food industries. At the moment she is leader of the Flagship Food Systems for Healthier Diets under the CGAIR funded Agriculture for Nutrition and Health research programme led by the International Food Policy Research Institute. This programme is carried in collaboration with Bioversity International, CIAT, IFPRI, IITA in Bangladesh, Vietnam, Ethiopia and Vietnam with the aim to guide transformations of food systems toward healthier diets for poor populations in a sustainable and equitable way. Countries of experience: Ethiopia, Nigeria, Vietnam, Bangladesh, Ghana, Malawi, India, Mali, Senegal, Kenya, Burkina Faso, Benin 